Pharmacol Ther

P\&T22317

(revised manuscript)

\title{
Serotonin receptors involved in antidepressant effects
}

\author{
Francesc Artigas \\ Department of Neurochemistry and Neuropharmacology, \\ Institut d'Investigacions Biomèdiques de Barcelona (IIBB-CSIC-IDIBAPS) \\ Centro de Investigación Biomédica en Red de Salud Mental (CIBERSAM)
}

Running title: 5-HT receptors and antidepressants

Corresponding author: Francesc Artigas, PhD; Dept. of Neurochemistry and Neuropharmacology, IIBB-CSIC (IDIBAPS), Rosselló, 161, $6^{\text {th }}$ floor, 08036 Barcelona, Spain. Phone: +3493-363 8314; Fax: +3493-363 8301; e-mail: fapnqi@iibb.csic.es 


\section{Abstract}

The neurotransmitter serotonin (5-hdroxytryptamine; 5-HT) has been implicated in the pathophysiology and treatment of major depression since the serendipitous discovery of antidepressant drugs in the 1950s. However, despite the generalised use of serotoninenhancing drugs, such as the selective serotonin reuptake inhibitors (SSRIs) and the dual serotonin and norepinephrine reuptake inhibitors (SNRIs), the exact neurobiological mechanisms involved in the therapeutic action of these drugs are poorly understood. Better knowledge of these mechanisms may help to identify new therapeutic targets and to overcome the two main limitations of current treatments: reduced efficacy and slowness of action. Here I review the preclinical and clinical evidence supporting the involvement of different 5-HT receptors in the therapeutic action of antidepressant drugs. Presynaptic $5-\mathrm{HT}_{1 \mathrm{~A}}$ and $5-\mathrm{HT}_{1 \mathrm{~B}}$ autoreceptors play a major detrimental role in antidepressant treatments, as their activation by the excess of the active (extracellular) $5-\mathrm{HT}$ fraction produced by serotonin transporter (SERT) blockade reduces presynaptic serotonergic function. Conversely, stimulation of postsynaptic 5$\mathrm{HT}_{1 \mathrm{~A}}$ receptors in corticolimbic networks appears beneficial for the antidepressant action. The 5$\mathrm{HT}_{2}$ receptor family is also involved as $5-\mathrm{HT}_{2 \mathrm{~A} / 2 \mathrm{C}}$ receptor blockade improves the antidepressant action of SSRIs, and recent data suggest that $5-\mathrm{HT}_{2 \mathrm{~B}}$ receptor activation enhances serotonergic activity. Less is known from the rest of postsynaptic 5- $\mathrm{HT}$ receptors. However, $5-\mathrm{HT}_{3}$ receptor blockade augments the 5-HT increase evoked by SERT inhibition, and 5- $\mathrm{HT}_{4}$ receptor activation may have antidepressant effects on its own. Finally, blockade of $5-\mathrm{HT}_{6}$ and $5-\mathrm{HT}_{7}$ receptors appears also to augment the antidepressant effects of SERT inhibition.

Keywords: Antidepressant drugs; Major depression; Serotonin transporter; Serotonin receptors; SSRI; SNRI

\section{Abbreviations}

5-HIAA, 5-hydroxyindoleacetic acid

5-HT, 5-hydroxytryptamine, serotonin

BDNF, brain-derived neurotrophic factor

CREB, cyclic AMP response element-binding

CNS, central nervous system

DA, dopamine 
DHPC, dorsal hippocampus

$\mathrm{DR}$, dorsal raphe nucleus

GABA, y-aminobutyric acid

LC; locus coeruleus

MDD, major depressive disorder

MnR, median raphe nucleus

mRNA, messenger ribonucleic acid

$\mathrm{NE}$, norepinephrine

NMDA, noncompetitive $\mathrm{N}$-methyl d-aspartate

PET, positron emission tomography

PFC, prefrontal cortex

$\mathrm{REM}$, rapid eye movement

SERT, serotonin transporter

SNRI, serotonin and norepinephrine reuptake inhibitors

SSRI, selective serotonin reuptake inhibitors

STR, dorsal striatum

VHPC, ventral hippocampus

VTA, ventral tegmental area 


\section{Table of contents}

1. Introduction

2. The serotonin system in depression

3. Serotonin receptors

- 3.1. 5-HT $1 \mathrm{~A}$ receptors

- 3.2. 5- $H T_{1 B}$ receptors

- 3.3. Other 5-HT 1 receptors

- 3.4. 5- $H T_{2 \mathrm{~A}}$ receptors

- 3.5. 5- $H T_{2 B}$ receptors

- 3.6. 5- $H T_{2 C}$ receptors

- 3.7.5-HT3 receptors

- 3.8. 5- $\mathrm{HT}_{4}$ receptors

- 3.9. 5-HT 6 receptors

- 3.10. 5-HT $T_{7}$ receptors

4. Conclusions and implications for new drug development 


\section{Introduction}

Major depressive disorder (MDD) is a severe psychiatric syndrome with high prevalence and socioeconomic impact (Andlin-Sobocki et al., 2005; Smith, 2011; Kessler et al., 2005). Although it is clear that depression results from, and can result in, changes in the functional neuroanatomy of the brain (Sheline et al., 1996; Duman et al., 1997; Drevets et al., 2008; Seminowicz et al., 2004), the underlying pathophysiology of MDD has not yet been clearly defined. Numerous clinical and preclinical studies indicate that a disturbance in central serotonin (5-hydroxytryptamine; 5-HT) activity is a key factor; however, other monoaminergic neurotransmitters (e.g. norepinephrine -NE- and dopamine -DA-) have also been implicated (Harro and Oreland, 2001; Nestler et al., 2002; Nestler and Carlezon, 2006). More recently, glutamatergic neurotransmission has been implicated, based on the observation that ketamine (noncompetitive $\mathrm{N}$-methyl d-aspartate -NMDA- receptor antagonist) shows rapid and persistent antidepressant effects (Zarate et al., 2006).

Despite the large body of research focusing on the mechanisms underlying antidepressant efficacy (Blier and de Montigny, 1994; Artigas et al., 1996; Celada et al., 2004; Berton and Nestler, 2006), current antidepressants remain limited - especially in terms of onset of action and overall efficacy (Trivedi et al., 2006; Rush et al., 2006; Rush et al, 2011). The aim of this article is to review our current knowledge of the role of the serotonergic system in depression, including the many serotonergic receptors identified, and how targeting these receptors in novel ways may lead to the development of new antidepressants.

\section{The serotonin system in depression}

Abnormalities in serotonergic function have been believed to be a common factor in several related mental illnesses since the 1950s (Woolley and Shaw, 1954). Since then, the link 
between serotonin and depression has been further clarified by clinical studies that have shown that an acute, transient relapse of depressive symptoms can be produced in subjects in remission using the irreversible 5-HT synthesis inhibitor $p$-chlorophenylalanine (Shopsin et al., 1975; Shopsin et al., 1976) or tryptophan depletion (Delgado et al., 1990; Price et al., 1990) to cause a temporary reduction in central serotonin levels. Overall, these studies show that clinical efficacy of antidepressant drugs depends on presynaptic serotonergic function. Similarly, other studies have shown reduced cerebrospinal fluid concentrations of the serotonin major metabolite - 5-hydroxyindoleacetic acid (5-HIAA) - in drug-free depressed patients (Asberg et al., 1976, Roy et al., 1989) as well as reduced concentrations of 5-HT and its main metabolite (5-HIAA) in the postmortem brain tissue of depressed and/or suicidal patients.

Perhaps the strongest evidence for the role of the serotonergic system in MDD is the efficacy of antidepressants that target the serotonin transporter (SERT) - namely, the selective serotonin reuptake inhibitors (SSRIs) and the dual serotonin and norepinephrine reuptake inhibitors (SNRIs) - which account for more than $90 \%$ of the global antidepressant market. A full review of the serotonergic system is beyond the scope of the present article but has been well covered in other comprehensive reviews (Azmitia and Whitaker-Azmitia, 1991; Jacobs and Azmitia, 1992; Smythies, 2005). However, before focusing on the numerous 5-HT receptors, it is important to understand the basic characteristics of the serotonergic system relevant to understanding the effects of antidepressant therapy (Box 1).

First, the serotonergic neurons of the mammalian brain comprise the most extensive and complex neurochemical network in the central nervous system (CNS) after that of glutamate, which makes up the basic wiring of the brain. It has been estimated that the human brain contains about 250000 5-HT neurons of a total of $10^{11}$ neurons (Jacobs and Azmitia, 1992). Importantly, whereas serotonergic neurons originate mainly in the brainstem dorsal and median 
raphe nuclei, their axons arborise over large areas such that they innervate almost every area of the brain with high densities of axonal varicosities. Hence, densities of $>10^{6}$ nerve terminals $/ \mathrm{mm}^{3}$ have been reported in rat neocortex (Beaudet and Descarries, 1976).

Second, whereas some serotonergic projections form classical chemical synapses, many do not, but instead release 5-HT in a paracrine manner (sometimes termed 'volume transmission'). Thirdly, serotonin neurons are tonically active with a slow $(\sim 1 \mathrm{~Hz})$ and regular activity that ceases during rapid eye movement sleep (REM-off neurons), in parallel with noradrenergic neurons of the locus coeruleus (Smythies, 2005). Finally, it is also important to understand that under normal conditions, the activity of serotonergic neurons is tightly controlled via a number of mechanisms including - among others - glutamatergic inputs from forebrain areas such as the prefrontal cortex (Celada et al., 2001; Fink et al., 1995; Martin-Ruiz et al., 2001a), tonic noradrenergic input from the pontine nuclei (Peyron et al., 1996; O'Leary et al., 2007; VanderMaelen and Aghajanian, 1983), inhibitory $\mathrm{Y}$-aminobutyric acid (GABA)-ergic inputs from local interneurons (Bagdy et al., 2000; Gervasoni et al., 2000; Varga et al., 2001) and dopaminergic input from the midbrain dopaminergic nuclei (Martin-Ruiz et al., 2001b). In addition, the serotonin system is involved in 'self-regulation' of serotonergic activity. Indeed, a key control mechanism of 5-HT neurons is self-inhibition through 5- $\mathrm{HT}_{1 \mathrm{~A}}$ autoreceptors, which will be discussed in detail later. Taken together, these basic anatomical and electrophysiological characteristics mean that changes in the activity of serotonergic neurons influence a large population of target neurons in the forebrain.

Considering the complex nature of the serotonergic system and the interplay with other neurochemical systems, numerous mechanisms may play a role in MDD development. Currently, mechanisms suggested include low neuronal production of serotonin or of postsynaptic receptors, reduced excitatory inputs or excessive self-inhibition, reduced 5-HT 
synthesis and/or tryptophan shortage. Regardless of the exact mechanisms, depression is attributable, at least in part, to abnormal transmission at central 5-HT synapses; therefore, agents that modulate serotonergic transmission in the brain are predicted to be effective antidepressants.

\section{5-HT receptors}

Following SSRI development, serotonergic targets other than SERT - namely, the 5-HT receptors - have received much research attention. Serotonin mediates its wide range of physiological functions through interactions with multiple receptors, and to date seven families of 5- $\mathrm{HT}$ receptors have been identified $\left(5-\mathrm{HT}_{1}-5-\mathrm{HT}_{7}\right)$, some of which have several receptor subtypes. Six of the seven subtypes are G-protein-coupled receptors, whereas the $5-\mathrm{HT}_{3}$ receptor is a ligand-gated cation channel (reviewed in Hoyer et al., 1994; Barnes and Sharp, 1999).

\section{1. $5-H T_{1 A}$ receptors}

The first major family - the 5- $\mathrm{HT}_{1}$ receptors - is linked to the inhibition of adenylate cyclase and mainly function as inhibitory presynaptic and postsynaptic receptors. Of this family, the role of the $5-\mathrm{HT}_{1 \mathrm{~A}}$ subtype in depression (more specifically in the mechanism of action of antidepressants) is relatively well-established. $5-\mathrm{HT}_{1 \mathrm{~A}}$ receptors are coupled to several intracellular signalling mechanism, of which two have received most attention, the negative coupling to adenylate cyclase and the opening of $K^{\star}$ channels (Barnes and Sharp, 1999; Raymond et al., 2001). 5- $\mathrm{HT}_{1 \mathrm{~A}}$ receptors are found in two main populations: 1) serotonin neurons of the midbrain raphe nuclei (as presynaptic autoreceptors); and 2) postsynaptic neurons mainly in the hippocampus, septum, amygdala and corticolimbic areas (SanabriaBohorquez et al., 2002; Pazos and Palacios, 1985; Pompeiano et al., 1992; Martinez et al., 2001; Santana et al., 2004). As mentioned above, 5- $\mathrm{HT}_{1 \mathrm{~A}}$ receptors play an important role in the 
self-regulation of the serotonergic system. Serotonergic activation of these receptors leads to opening of potassium channels in the cell membrane and hyperpolarisation of the cell, which results in a reduction in the discharge rate (Sprouse and Aghajanian, 1987; Sprouse and Aghajanian, 1986). Given the remarkable role of the neuronal discharge on the overall activity of the whole serotonergic system, the reduction in firing rate evoked by $5-\mathrm{HT}_{1 \mathrm{~A}}$ agonists translates immediately into a widespread reduction of 5-HT release in most brain areas, yet with a preferential effect on dorsal raphe-innervated regions (Hjorth and Sharp, 1991; Adell et al., 1993; Casanovas and Artigas, 1996; Casanovas et al., 1997).

Activation of $5-\mathrm{HT}_{1 \mathrm{~A}}$ autoreceptors by endogenous $5-\mathrm{HT}$ plays a fundamental role in the physiological control of the activity of ascending 5-HT neurons. During waking periods, 5-HT neurons show a slow and regular discharge rate (pacemaker activity) (Jacobs and Azmitia, 1992). Under conditions of excessive excitatory input, such as those produced by stress, an increased 5-HT release occurs in the vicinity of cell bodies that activates inhibitory $5-\mathrm{HT}_{1 \mathrm{~A}}$ autoreceptors and helps to keep 5-HT neuronal firing low and regular (Adell et al., 1997; Celada et al., 2001; Martin-Ruiz and Ugedo, 2001). Thus, 5- $\mathrm{HT}_{1 \mathrm{~A}}$ autoreceptors act as physiological 'safety valves' that help to maintain the homeostasis of the system. This physiological negative feedback mechanism plays a detrimental role in the mechanism of action of antidepressant drugs. Hence, the acute administration of antidepressants (tricyclic drugs, monoamine oxidase inhibitors and SSRIs) produces a very large increase of extracellular 5-HT in the midbrain raphe (Adell and Artigas, 1991; Bel and Artigas, 1992; Celada and Artigas, 1993), which activates 5$\mathrm{HT}_{1 \mathrm{~A}}$ receptors and so reduces 5-HT cell firing (Blier and de Montigny, 1994) and terminal 5-HT release (Romero et al., 1996; Artigas et al., 1996) (Fig. 1). Importantly, the effectiveness of this negative feedback pathway in inhibiting the effects of SSRIs clearly declines with prolonged treatment and is likely to result from the serotonin-induced desensitisation of raphe $5-\mathrm{HT}_{1 \mathrm{~A}}$ autoreceptors (Blier and de Montigny, 1994; El Mansari et al., 2005; Hervas et al., 2001), which 
allows extracellular 5-HT to increase markedly more than after single administration (Bel and Artigas, 1993; Ferrer and Artigas, 1994; Hervas et al., 2001). It is thought that this feedback loop probably explains much of the slow and delayed clinical action of antidepressant drugs (Artigas et al., 1996; Artigas et al., 2001).

5- $\mathrm{HT}_{1 \mathrm{~A}}$ receptor abnormalities have been reported in patients with MDD. Hence, postmortem and neuroimaging studies suggest an increased density of $5-\mathrm{HT}_{1 \mathrm{~A}}$ autoreceptors in major depressives compared with control subjects (Stockmeier et al., 1998; Parsey et al., 2006; Boldrini et al.,. 2008). Likewise, genetic studies have shown that individuals with elevated density or activity of $5-\mathrm{HT}_{1 \mathrm{~A}}$ autoreceptors are more susceptible to mood disorders and respond poorly to antidepressants (Lemonde et al., 2003; Neff et al., 2009). However, postsynaptic 5$\mathrm{HT}_{1 \mathrm{~A}}$ receptors have been shown to be unaltered or reduced in depressed patients, and this alteration is not sensitive to antidepressant treatment (Bhagwagar et al., 2004).

In the 1990s, I proposed that " $5-H T_{1 A}$ receptor antagonists could accelerate (and perhaps augment) the clinical effects of antidepressants by preventing this negative feedback" (Artigas, 1993) and showed that combining SSRI treatment with the mixed $5-\mathrm{HT}_{1 \mathrm{~A}} / \mathrm{B}$-adrenoceptor antagonist pindolol (the only potential $5-\mathrm{HT}_{1 \mathrm{~A}}$ antagonist available for human use by that time) markedly reduced the latency of the antidepressant response and increased the clinical response in previously untreated patients with MDD (Artigas et al., 1994; Artigas et al., 2006; see metanalyses in Whale et al., 2010; Ballesteros and Callado, 2004). However, pindolol additon was ineffective in treatment-resistant depressed patients (Perez et al., 1999), and the scarcity of $5-\mathrm{HT}_{1 \mathrm{~A}}$ receptor antagonists available for human use has limited the use of the 'pindolol strategy' to accelerate/enhance the antidepressant effects of SSRI. Since then, it has been of considerable interest to evaluate potential antidepressants that incorporate an action at 5- $\mathrm{HT}_{1 \mathrm{~A}}$ receptors into their mechanism of action. To the best of my knowledge, two new 
antidepressants [vilazodone, approved in 2011; and vortioxetine (Lu AA21004), in development] inhibit 5-HT reuptake and show partial agonism at 5- $\mathrm{HT}_{1 \mathrm{~A}}$ receptors (Page et al., 2002; Mork et al., 2012). Another drug (VN-2222; Romero et al., 2003), similar to vilazodone, was not developed due to industrial problems.

As well as improving the onset of action of SSRIs, 5- $\mathrm{HT}_{1 \mathrm{~A}}$ agents are known to exert their own, potentially therapeutic, actions. $5-\mathrm{HT}_{1 \mathrm{~A}}$ ligands with partial agonist activity seem to possess antianxiety (Schreiber and De Vry, 1993), antidepressant (Robinson et al., 1990), antiaggressive (Sanchez and Hyttel, 1994, de Boer and Koolhaas, 2005), and perhaps anticraving (Naranjo and Bremner, 1993) and anticataleptic (Prinssen et al., 2002) properties. Further, transgenic mice with a reduced expression of presynaptic $5-\mathrm{HT}_{1 \mathrm{~A}}$ receptors (Richardson-Jones et al., 2010) and wild-type mice with siRNA-mediated supression of 5-HT $1 \mathrm{~A}$ autoreceptors have been reported to display antidepressant-like behaviour (Bortolozzi et al., 2012).

It has been noted that prolonged antidepressant treatments result in a tonic activation of $5-\mathrm{HT}_{1 \mathrm{~A}}$ receptors in the dorsal hippocampus (CA3 region) (Haddjeri et al., 1998) and that activation of $5-\mathrm{HT}_{1 \mathrm{~A}}$ receptors in the dentate gyrus increases hippocampal neurogenesis (Jacobs et al., 2000). These observations, together with the antidepressant properties of $5-\mathrm{HT}_{1 \mathrm{~A}}$ agonists in preclinical tests (see Cryan et al., 2005 for review), have led to the suggestion of $5-\mathrm{HT}_{1 \mathrm{~A}}$ agonists as a new class of antidepressants (Blier and Ward, 2003). However, although some agents of this kind (e.g. buspirone, gepirone) show antidepressant efficacy in placebo-controlled trials, their efficacy appears to be lower than that of SSRIs, and these drugs have not succeeded in the antidepressant market. Two main reasons may account for the clinical failure of $5-\mathrm{HT}_{1 \mathrm{~A}}$ agonists. Firstly, most agents of this kind (especially the azapirones) show preferential activation of presynaptic $5-\mathrm{HT}_{1 \mathrm{~A}}$ receptors. This reduces $5-\mathrm{HT}$ cell firing and terminal $5-\mathrm{HT}$ 
release. Second, with few exceptions, these agents tend to show a reduced efficacy at postsynaptic $5-\mathrm{HT}_{1 \mathrm{~A}}$ receptors. Thus, acute treatment with $5-\mathrm{HT}_{1 \mathrm{~A}}$ receptors replaces the endogenous transmitter (5-HT, with a 100\% efficacy) from postsynaptic sites by the partial agonist, with a lower efficacy than 5-HT. This results in a paradoxical reduction of the tone at postsynaptic $5-\mathrm{HT}_{1 \mathrm{~A}}$ receptors. Higher doses (as those used in experimental animals) likely result in a greater activation of postsynaptic $5-\mathrm{HT}_{1 \mathrm{~A}}$ receptors, which may explain the positive results in animal tests. The importance of activating postsynaptic $5-\mathrm{HT}_{1 \mathrm{~A}}$ receptors for full antidepressant efficacy has been highlighted by a recent study showing that addition of the selective 5- $\mathrm{HT}_{1 \mathrm{~A}}$ receptor antagonist DU125530 to fluoxetine treatment did not accelerate nor enhance the efficacy of fluoxetine in a randomised, placebo-controlled, double-blind clinical trial. DU125530 has equal potency and occupancy of pre- and postsynaptic 5- $\mathrm{HT}_{1 \mathrm{~A}}$ receptors (Rabiner et al., 2002), and it is suggested that the blockade of postsynaptic 5- $\mathrm{HT}_{1 \mathrm{~A}}$ receptors cancelled the benefits obtained by enhancing presynaptic serotonergic function (Scorza et al., 2011).

Unlike azapirones and other first-generation 5- $\mathrm{HT}_{1 \mathrm{~A}}$ agonists, recently developed agonists hold promise to overcome these problems. For example, F15599 shows eightfold selectivity for postsynaptic $5-\mathrm{HT}_{1 \mathrm{~A}}$ receptors in hippocampus vs. raphe 5- $\mathrm{HT}_{1 \mathrm{~A}}$ autoreceptors (Llado-Pelfort et al., 2010). Consistent with this preferential activation of postsynaptic $5-\mathrm{HT}_{1 \mathrm{~A}}$ receptors, this agent shows superiority vs. classical $5-\mathrm{HT}_{1 \mathrm{~A}}$ agonists in cognitive tests (Depoortere et al., 2010).

\section{2. $5-H T_{1 B}$ receptors}

Like the 5- $\mathrm{HT}_{1 \mathrm{~A}}$ receptor, 5- $\mathrm{HT}_{1 \mathrm{~B}}$ receptors are located pre- and postsynaptically and negatively coupled to adenylate cyclase. Yet unlike $5-\mathrm{HT}_{1 \mathrm{~A}}$ autoreceptors, which are located in somatodendritically on $5-\mathrm{HT}$ neurons, $5-\mathrm{HT}_{1 \mathrm{~B}}$ autoreceptors are located on serotonergic axons, 
where they locally regulate $5-\mathrm{HT}$ synthesis and release. Postsynaptic $5-\mathrm{HT}_{1 \mathrm{~B}}$ receptors (or heteroreceptors) are predominantly located in motor control centres such as the basal ganglia, where they control synaptic transmission (Castro et al., 1998; Sari, 2004). Evidence implicating $5-\mathrm{HT}_{1 \mathrm{~B}}$ receptors in the pathophysiology of depression comes from a number of converging lines of research. Two common genetic polymorphisms of 5- $\mathrm{HT}_{1 \mathrm{~B}}$ receptors, $\mathrm{G} 861 \mathrm{C}$ (Huang et al., 2003) and C129T (Ruf and Bhagwagar, 2009), have been implicated in MDD and affective disorders. $5-\mathrm{HT}_{1 \mathrm{~B}}$ receptor antagonists administered alone or with antidepressants have been shown to be effective in preclinical models of depression (Tatarczynska et al., 2004). On the other hand, the activation of 5- $\mathrm{HT}_{1 \mathrm{~B}}$ heteroceptors induces antidepressant-like behaviour (Chenu et al., 2008).

Recent interest has also focused on p11, an s100 EF-hand protein family protein that colocalizes with 5- $\mathrm{HT}_{1 \mathrm{~B}}$ and 5- $\mathrm{HT}_{4}$ receptors (Egeland et al., 2011). P11 plays a central role in the modulation of $5-\mathrm{HT}_{1 \mathrm{~B}}$ receptor function and is dysregulated in preclinical models of depression and postmortem MDD samples (Svenningsson et al., 2006). As with the 5-HT $1 \mathrm{~A}$ receptors, acute SSRI administration activates terminal $5-\mathrm{HT}_{1 \mathrm{~B}}$ receptors, thus reducing $5-\mathrm{HT}$ synthesis and release. Likewise, chronic administration of SSRI also results in desensitisation of terminal $5-\mathrm{HT}_{1 \mathrm{~B}}$ autoreceptors (Neumaier et al., 1996), suggesting that plasticity in both the 5$\mathrm{HT}_{1 \mathrm{~A}}-$ and $5-\mathrm{HT}_{1 \mathrm{~B}}-$ mediated autoregulatory function may be important in the therapeutic profile of SSRI. As observed with $5-\mathrm{HT}_{1 \mathrm{~A}}$ receptors, the administration of $5-\mathrm{HT}_{1 \mathrm{~B}}$ receptor antagonists augments the neurochemical and behavioural effects of SSRIs (Gobert et al., 1997, 2000a; Rollema et al., 1996, Hervas et al., 2000). Interestingly, co-administration of the selective $5-\mathrm{HT}_{1 \mathrm{~A}}$ antagonist WAY-100635 and the 5- $\mathrm{HT}_{1 \mathrm{~B}}$ receptor antagonist SB-224289 acts additively to potentiate the neurochemical actions of the SSRI, fluoxetine (Fig. 1). This has led to the suggestion that combining $5-\mathrm{HT}_{1 \mathrm{~A}}$ and $5-\mathrm{HT}_{1 \mathrm{~B}}$ receptor antagonism can elevate serotonin and therefore potentially be an effective strategy to treat depression. 


\subsection{Other $5-H T_{1}$ receptors}

Unlike the 5- $\mathrm{HT}_{1 \mathrm{~A}}$ and $5-\mathrm{HT}_{1 \mathrm{~B}}$ receptors, the clinical significance of the other $5-\mathrm{HT}_{1-\text { like }}\left(5-\mathrm{HT}_{1 \mathrm{D}}, 5-\right.$ $\mathrm{HT}_{1 \mathrm{E}}, 5-\mathrm{HT}_{1 \mathrm{~F}}$ ) receptors remain less clear - although there is limited preclinical evidence linking some of these receptors to depression and associated conditions. Studies show that patients with depression have impaired sensitivity of the postsynaptic 5- $\mathrm{HT}_{1 \mathrm{D}}$ receptors (Whale et al., 2001). Similarly, another postmortem study of antidepressant-free suicide victims with a confirmed history of depression found a significantly higher density of $5-\mathrm{HT}_{1 \mathrm{D}}$ receptors in the globus pallidus (Lowther et al., 1997). The $5-\mathrm{HT}_{1 \mathrm{E}}$ receptor is highly expressed in the human frontal cortex and hippocampus, and it has been suggested that this distribution implies that 5$\mathrm{HT}_{1 \mathrm{E}}$ receptors might be linked to cognition and memory (Klein et al., 2011).

\section{4. $5-H T_{2 A}$ receptors}

5- $\mathrm{HT}_{2 \mathrm{~A}}$ receptors, like the other members of the $5-\mathrm{HT}_{2}$ receptor family, are preferentially coupled to $\mathrm{Gq} / 11$ to increase inositol phosphates and cytosolic $\left[\mathrm{Ca}^{2+}\right]$, They are widely distributed at varying densities throughout the brain, with the highest density in the neocortex (Burnet et al., 1995). There is generally a close overlap between the distribution of $5-\mathrm{HT}_{2 \mathrm{~A}} \mathrm{mRNA}$ and immunoreactivity, suggesting a postsynaptic location (Lopez-Gimenez et al., 2001b). In the cortex, $5-\mathrm{HT}_{2 \mathrm{~A}}$ receptors have been shown to be localised on GABAergic interneurons as well as glutamatergic projection neurons in human and rodent brain (Santana et al., 2004; de Almeida and Mengod, 2007)

Numerous antidepressants and antipsychotic agents bind with relatively high affinity at $5-\mathrm{HT}_{2 \mathrm{~A}}$ receptors. Although there is no direct correlation between their receptor affinities and clinically effective doses, cumulative evidence indicates that the $5-\mathrm{HT}_{2 \mathrm{~A}}$ receptor plays a role in depression. Several clinical studies have shown that atypical antipsychotic drugs (Carvalho et 
al., 2008) and the antidepressant mirtazapine with affinity for $\alpha_{2}$-adrenoceptors and 5-HT $2 \mathrm{~A}$ receptors (Carpenter et al., 1999) augment the clinical response to SSRIs in treatment-resistant patients (Shelton et al., 2001). One common feature of these agents is their ability to occupy 5$\mathrm{HT}_{2}$ receptors in the brain at clinical doses and more specifically to block $5-\mathrm{HT}_{2 \mathrm{~A}}$-mediated responses (Marek et al., 2003). Given the large co-expression of 5- $\mathrm{HT}_{1 \mathrm{~A}}$ and 5- $\mathrm{HT}_{2 \mathrm{~A}}$ receptors in the neocortex (Amargos-Bosch et al., 2004), blockade of 5- $\mathrm{HT}_{2 \mathrm{~A}}$ receptors might enhance the 5$\mathrm{HT}_{1 \mathrm{~A}}$ receptor-mediated neurotransmission in cortical and limbic areas, an effect likely linked to the antidepressant efficacy (Fig. 2). Interestingly, the ventral parts of the anterior cingulate contain a higher proportion of $5-\mathrm{HT}_{1 \mathrm{~A}}$ than of $5-\mathrm{HT}_{2 \mathrm{~A}}$ receptors in the rodent (Santana et al., 2004) and human brains (Palomero-Gallagher et al., 2009), suggesting that SSRIs may preferentially inhibit neuronal activity in this region compared to more dorsal cingulate areas. This is an interesting observation, given the role of the subcallosal cingulate (mainly Broadman area 25) in the improvement of treatment-resistant depressive patients by deep brain stimulation (Mayberg et al., 2005; Kennedy et al., 2011; Puigdemonet et al., 2012).

Also, chronic administration of $5-\mathrm{HT}_{2 \mathrm{~A}}$ antagonists has been reported to result in a paradoxical down-regulation of 5- $\mathrm{HT}_{2 \mathrm{~A}}$ receptors (Gray and Roth, 2001), which is predicted to be of benefit in the treatment of depression. Further, preclinical studies indicate that $5-\mathrm{HT}_{2 \mathrm{~A}}$ antagonists possess anxiolytic properties, and the $5-\mathrm{HT}_{2 \mathrm{~A}}$ antagonist ritanserin has been shown to have an antianxiety effect in humans (Bressa et al., 1987).

\section{5. $5-H T_{2 B}$ receptors}

The $5-\mathrm{HT}_{2 \mathrm{~B}}$ receptor is largely expressed in peripheral tissues and has a restricted distribution in mammalian brain (Kursar et al., 1994; Bonhaus et al., 1995; Duxon et al., 1997). Interestingly, the $5-\mathrm{HT}_{2 \mathrm{~B}}$ receptor mRNA is found in the dorsal raphe nucleus, suggesting a potential autoreceptor role (Bonaventure et al., 2002). 5- $\mathrm{HT}_{2 \mathrm{~B}}$ receptors mediate the well-known 
contraction of rat fundus induced by $5-\mathrm{HT}$ and appear to be involved in heart development (Nebigil et al., 2000). However, despite the limited knowledge regarding $5-\mathrm{HT}_{2 \mathrm{~B}}$ receptor function in CNS, a recent study indicates its involvement in SSRI-mediated actions, showing also antidepressant-like properties of selective $5-\mathrm{HT}_{2 \mathrm{~B}}$ receptor agonists (Diaz et al. 2012). The same study reports on the presence of $5-\mathrm{HT}_{2 \mathrm{~B}}$ receptors in dorsal raphe 5- $\mathrm{HT}$ neurons and their stimulatory role on $5-\mathrm{HT}$ release. However, given the role of $5-\mathrm{HT}_{2 \mathrm{~B}}$ receptors in the peripheral actions of 5-HT, potential new antidepressants targeting $5-\mathrm{HT}_{2 \mathrm{~B}}$ receptors may have important pulmonary and cardiovascular side effects.

\subsection{5-HT 2 receptors}

5- $\mathrm{HT}_{2 \mathrm{C}}$ receptors are predominantly located in the choroids plexus, cerebral cortex, hippocampus, substantia nigra and cerebellum (Abramowski et al., 1995) and, like the 5- $\mathrm{HT}_{2 \mathrm{~A}}$ receptor, have been implicated in many processes, including mood, motor behaviour and appetite (Millan, 2005). Likewise, alterations in their functional status have been detected in anxiodepressive states (Niswender et al., 2001; Wood, 2003), and 5- $\mathrm{HT}_{2 \mathrm{C}}$ sites are known to be involved in the actions of several classes of antidepressant drugs.

Although $5-\mathrm{HT}_{2 \mathrm{C}}$ receptors usually have a somatodendritic location, they may also be located on axon terminals in certain areas such as the septum and interpeduncular nucleus (presence of binding sites without mRNA expression) (Lopez-Gimenez et al., 2001a). Of interest, the localisation of $5-\mathrm{HT}_{2 \mathrm{C}}$ receptors in relation to serotonergic and GABAergic neurons has been studied in the anterior raphe nuclei. Such studies have found that $5-\mathrm{HT}_{2 \mathrm{C}}$ receptors are preferentially located on GABAergic interneurons (and not on serotonergic neurons), thereby supporting the idea that excitation of GABAergic interneurons through these $5-\mathrm{HT}_{2 \mathrm{C}}$ receptors is important in the suppression of serotonergic cell firing in the dorsal raphe and surrounding areas (Serrats et al., 2005). Likewise, $5-\mathrm{HT}_{2 \mathrm{C}}$ receptor immunoreactivity has been reported in 
GABAergic cells of the prefrontal cortex (Liu et al., 2007) and in dopamine and GABA neurons of the mesolimbic pathway (Bubar et al., 2011).

An altered editing of the mRNA encoding $5-\mathrm{HT}_{2 \mathrm{C}}$ receptors has been reported in the prefrotnal cortex of depressed suicide victims (Gurevich et al., 2002), suggesting an abnormal function of the receptor protein. Desensitisation of $5-\mathrm{HT}_{2}$ receptors is also reported following chronic SSRI treatment. Preclinical data show that $5-\mathrm{HT}_{2 \mathrm{C}}$ antagonism augments the neurochemical and behavioural effects of SSRIs. For example, preclinical studies have shown that selective and nonselective 5- $\mathrm{HT}_{2 \mathrm{C}}$ antagonists, potentiate the neurochemical effects of SSRIs on hippocampal and cortical extracellular 5-HT levels (Cremers et al., 2007; Cremers et al., 2004) and produces marked augmentation of the antidepressant effects of SSRIs in behavioural models of depression (Cremers et al., 2004). Despite the robust neurochemical effects when these agents are combined, 5- $\mathrm{HT}_{2 \mathrm{C}}$ receptor antagonism alone has no significant effects on extracellular serotonin (Cremers et al., 2004). In contrast, various $5-\mathrm{HT}_{2 \mathrm{C}}$ receptor agonists were active in the forced swim test, suggesting antidepressant efficacy (Cryan and Lucki, 2000).

Additionally, $5-\mathrm{HT}_{2 \mathrm{C}}$ receptors are involved in the tonic modulation of dopaminergic activity (Gobert et al., 2000b; Invernizzi et al., 2007). The role of the meslimbic/mesocrotical DA systems in schizophrenia together with the high affinity of atypical antipsychoitc drugs $5-\mathrm{HT}_{2} \mathrm{C}$ receptors has prompted the interest in this receptor (Meltzer et al., 2003). However, the modulation of the ascending dopaminergic activity may be also of interest in antidepressant drug development. Hence, $5-\mathrm{HT}_{2}$ receptors have been reported to be involved in antidepressant-like effects in the forced swim test (Clenet et al., 2001). 


\section{7. $5-H T_{3}$ receptors}

The $5-\mathrm{HT}_{3}$ receptor is unique among all monoamine receptors in that it directly gates an ion channel-inducing rapid depolarisation that, in turn, causes the release of neurotransmitters and/or peptides. It is found throughout the brain and CNS and is in relatively high concentrations in the spinal cord and brainstem (area postrema), where it regulates vomiting. A number of 5$\mathrm{HT}_{3}$ receptor antagonists have been developed as antiemetics to be used with cancer chemotherapy. An antidepressant drug (litoxetine) was developed in the 1990s, combining SERT inhibition and 5- $\mathrm{HT}_{3}$ antagonism to prevent SSRI-induced gastrointestinal side effects (Angel et al., 1993).

Within the forebrain, 5- $\mathrm{HT}_{3}$ receptors have been found in the entorhinal, frontal and cingulate cortices, hippocampus, and amygdala (Thompson and Lummis, 2006). Immunohistochemical studies indicate that there is a differential cellular localisation of postsynaptic $5-\mathrm{HT}_{3}$ receptors within different central regions, depending on the nature of the neurons containing $5-\mathrm{HT}_{3}$ receptors. For instance, $5-\mathrm{HT}_{3}$ receptor immunoreactivity was most abundant in postsynaptic dendrite sites in the hippocampus, but was primarily associated with presynaptic nerve endings in amygdala (Miquel et al., 2002).

Importantly, 5- $\mathrm{HT}_{3}$ receptors control dopamine and acetylcholine release. Likewise, they control the GABAergic system and this interplay with other neurotransmitter systems (see below) is suggested to be a primary mechanism of effect for $5-\mathrm{HT}_{3}$ ligands. Thus, different types of GABAergic interneurons in forebrain express 5- $\mathrm{HT}_{3}$ receptors (Morales and Bloom, 1997; Puig et al., 2004). The physiological excitation of 5-HT neurons excites cortical (and possibly hippocampal) GABAergic neurons (Puig et al., 2004), an effect that likely results in the inhibition of neighbouring excitatory neurons via $\mathrm{GABA}_{A}$ and $G A B A_{B}$ receptors. Limited preclinical 
evidence also suggests that the $5-\mathrm{HT}_{3}$ receptor plays a role in a variety of psychological/psychiatric disorders; however, the use of $5-\mathrm{HT}_{3}$ receptor antagonists has met with little success. Nevertheless, there is accumulating evidence of interaction of antidepressant dugs with $5-\mathrm{HT}_{3}$ receptors. Thus, antidepressant drugs with different mechanism of action show affinity for 5- $\mathrm{HT}_{3}$ receptors (Lucchelli et al., 1995) and behave as functional antagonists (Eisensamer et al., 2003). Likewise, chronic fluoxetine treatment desensitises 5- $\mathrm{HT}_{3}$ receptors (Fan, 1994), and SERT knockout mice show enhanced 5- $\mathrm{HT}_{3}$ receptor density compared with wild-type mice (Mossner et al., 2004). More recently, it has been shown that $5-\mathrm{HT}_{3}$ receptor blockade with ondansetron potentiates the increase in extracellular 5-HT produced by citalopram in rat forebrain (Mork et al., 2012) Unlike the augmenting properties of $5-\mathrm{HT}_{1 \mathrm{~A}}$ and 5 $\mathrm{HT}_{1 \mathrm{~B}}$ receptor antagonists, involving presynaptic interactions at somatodendritic and terminal levels, this observation likely involves long loops from prefrontal cortex to midbrain serotonergic neurons (Fig. 3). Several reports also suggest a relationship between 5- $\mathrm{HT}_{3}$ receptors and anxiolytic/antidepressant behaviour. For example, transgenic knockout mice with deletion of the 5- $\mathrm{HT}_{3}$ receptor exhibit anxiolytic behaviour (Kelley et al., 2003), in agreement with the anxiolytic effects of $5-\mathrm{HT}_{3}$ receptor antagonists (Barnes et al., 1992).

The use of $5-\mathrm{HT}_{3}$ receptor antagonists have also been employed for the alleviation of substance abuse, a common comorbidity with most psychiatric disorders, including MDD (Ostacher, 2007). In this respect, $5-\mathrm{HT}_{3}$ receptor antagonists have been reported to be particularly effective at reducing ethanol and morphine self-administration (Costall et al., 1993, Engleman et al., 2008). It is also interesting to note that a variety of antipsychotic drugs are noncompetitive $5-\mathrm{HT}_{3}$ receptor antagonists, and it has been suggested that this functional antagonism may contribute to their antipsychotic efficacy (Rammes et al., 2004). In addition, 5- $\mathrm{HT}_{3}$ antagonists abolish the emotion-potentiated startle effect in humans (Harmer et al., 2006) and reverse helpless behaviour in rats (Martin et al., 1992). Likewise, 5- $\mathrm{HT}_{3}$ receptor agonism attenuates 
antidepressant-like effects in the forced swim test in rats (Nakagawa et al., 1998) and a 5-HT receptor antagonist reduced immobility in the forced swim test (Kos et al., 2006). In line with these observations, the $5-\mathrm{HT}_{3}$ receptor antagonist ondansetron showed antidepressant-like properties in the tail suspension and forced swim tests, augmenting also the effects of fluoxetine (Kos et al., 2006). Interestingly, the novel antidepressant drug vortioxetine [currently in development ( Baldwin et al., 2011); Alvarez et al., 2012) ] shows nanomolar affinity for several 5-HT receptors, including 5- $\mathrm{HT}_{3}$ receptors (Mork et al., 2012), the clinical relevance of which deserves further exploration.

\section{8. $5-H T_{4}$ receptors}

$5-\mathrm{HT}_{4}$ receptors are located predominantly in the putamen, caudate nucleus, hippocampus, nucleus accumbens, globus pallidus and substantia nigra; and to a lesser extent in the neocortex, raphe and pontine nuclei and some areas of the thalamus (Varnas et al., 2003). Positron emission tomography (PET) scan studies show a somewhat more restricted regional distribution in human brain, with a high $5-\mathrm{HT}_{4}$ receptor density in the caudate-putamen and much lower densities in frontal cortex and hippocampus (Marner et al., 2010). These receptors appear to be involved in the expression of genes of synaptic plasticity (Vidal et al., 2011), a common action of antidepressant drugs (Pittenger and Duman, 2008). The $5-\mathrm{HT}_{4}$ receptor interacts with $\mathrm{p} 11$, a protein required for antidepressant effects mediated by $5-\mathrm{HT}_{1 \mathrm{~B}}$ and $5-\mathrm{HT}_{4}$ receptors (Warner-Schmidt et al., 2009). Moreover, 5- $\mathrm{HT}_{4}$ knockout mice show an exaggerated inhibitory response of 5-HT neurons to the SSRI citalopram (Conductier et al., 2006), suggesting that $5-\mathrm{HT}_{4}$ receptors are involved in the maintenance of the firing activity of 5-HT neurons during SERT inhibition. Thus, as observed with 5- $\mathrm{HT}_{1 \mathrm{~A}}$ and $5-\mathrm{HT}_{2 \mathrm{~A}}$ receptors (Celada et al., 2001; Martín-Ruiz et al., 2001a), 5- $\mathrm{HT}_{4}$ receptors in prefrontal cortex control the firing rate of midbrain serotonergic neurons via descending inputs (Lucas et al., 2005) (Fig. 3). Moreover, 5- 
$\mathrm{HT}_{4}$ receptors mediate the synaptic transmission between the dentate gyrus and CA3 through the mossy fibre pathway. Interestingly, fluoxetine had a normalising effect on this pathway via 5$\mathrm{HT}_{4}$ receptor activation (Kobayashi et al., 2008).

Preclinical studies show that administration of the $5-\mathrm{HT}_{4}$ agonists $\mathrm{RS} 67333$ and prucalopride reduces immobility in the forced swim test, thereby displaying the potential of the $5-\mathrm{HT}_{4}$ receptor as a target for new antidepressant treatments (Lucas et al., 2007). Moreover, these studies show that administration of these agonists modifies rat brain parameters considered to be key markers of antidepressant action - namely, desensitisation of 5- $\mathrm{HT}_{1 \mathrm{~A}}$ autoreceptors, increased tonus on hippocampal postsynaptic $5-\mathrm{HT}_{1 \mathrm{~A}}$ receptors, and enhanced phosphorylation of the CREB protein and neurogenesis in the hippocampus. Importantly, these effects were already present after only 3 days' treatment (Lucas et al., 2007), whereas they are usually observed only after 2- to 3-week treatments with SSRIs. It has been suggested that the more rapid response to $5-\mathrm{HT}_{4}$ agonism is probably the result of parallel rapid and sustained activation of 5HT neuronal firing in the dorsal raphe nucleus (Duman, 2007). Increased 5-HT neuronal firing could also underlie the apparently greater efficacy of the $5-\mathrm{HT}_{4}$ agonists relative to SSRIs, as the effect of reuptake inhibition is dependent on basal rates of 5-HT cell firing. Since the raphe nuclei do not appear to express $5-\mathrm{HT}_{4}$ receptors, the ability of $5-\mathrm{HT}_{4}$ receptors to stimulate serotonergic firing appears to involve activation of receptors located on neurons in the prefrontal cortex (Lucas et al., 2005). Although the identity of the cells that express $5-\mathrm{HT}_{4}$ receptors and their connections with the serotonergic neurons of the dorsal raphe nucleus is not yet known, it is possible that they project to other regions that contribute to the antidepressant actions of 5$\mathrm{HT}_{4}$ agonists (Duman, 2007). 


\section{9. $5-H T_{6}$ receptors}

5- $\mathrm{HT}_{6}$ receptors are postsynaptic receptors with the highest expression in the striatum, nucleus accumbens, olfactory tubercle, and cortex, with moderate density in the amygdala, hippocampus, hypothalamus, thalamus and cerebellum (Branchek and Blackburn, 2000). There is considerable evidence for this receptor subtype playing a role in learning and memory (Rosse and Schaffhauser, 2010), as well as centrally regulated feeding behaviour (Heal et al., 2008). Hence, 5- $\mathrm{HT}_{6}$ receptors are considered new targets for cognitive enhancement (Mitchell et al., 2006). Several tricyclic antidepressant drugs, such as amitriptyline, and atypical antidepressants, such as mianserin, display nanomolar affinity and antagonist activity at the 5$\mathrm{HT}_{6}$ receptor (Monsma et al., 1993). This finding, together with the distribution of the receptor in limbic and cortical brain areas, has led to the suggestion that $5-\mathrm{HT}_{6}$ receptors play an important role in the pathogenesis and/or treatment of depression (Monsma et al., 1993).

Preclinical studies have shown that 5- $\mathrm{HT}_{6}$ antagonists such as SB-399885 exert an antidepressant-like effect in the forced swim and tail suspension tests in rodents (rats and mice) (Wesolowska and Nikiforuk, 2007). Moreover, combining a subeffective dose of SB-399885 with ineffective doses of imipramine, desipramine, bupropion or moclobemide was shown to have an antidepressant effect in the forced swim test in rats (Wesolowska and Nikiforuk, 2008). This suggests that inhibition of the $5-\mathrm{HT}_{6}$ receptor synergistically potentiates the effect of clinically used antidepressants, and it is interesting to speculate whether combining a lower dose of an antidepressant with a 5- $\mathrm{HT}_{6}$ receptor antagonist might accelerate the onset of action and minimize the side-effect profiles. Confusingly, other preclinical studies have indicated that $5-\mathrm{HT}_{6}$ agonists may also be useful in treating depression. For example, it has been suggested that 5$\mathrm{HT}_{6}$ receptor stimulation may be a mechanism initiating some of the biochemical and behavioural outcomes of antidepressants such as fluoxetine (Svenningsson et al., 2007). On the other hand, the $5-\mathrm{HT}_{6}$ receptor agonist LY-586713 increased hippocampal BDNF expression - a 
cellular marker of antidepressant action - after single administration (de Foubert et al., 2007) whereas SSRIs require repeated administration to elicit the same effect (Pittenger and Duman, 2008). On the same line, the $5-\mathrm{HT}_{6}$ receptor agonist EMD 386088 produced antidepressant-like and anxiolytic effects after intra-hippocampal administration (Nikiforuk et al., 2011). Thus, it is uncertain whether antagonists or agonists of this receptor will best treat depression. Moreover, the exact mechanism of action of $5-\mathrm{HT}_{6}$ ligands to elicit antidepressant-like effects is unknown and may involve changes in other neurotransmitter systems (Dawson and Li, 2003; Wesolowska, 2007).

\subsection{0. $5-H T_{7}$ receptors}

The $5-\mathrm{HT}_{7}$ receptor, as first cloned in 1993 , is highly expressed in the thalamus, hypothalamus, hippocampus and cortex (Hedlund and Sutcliffe, 2004). Findings from immunolocalisation and autoradiography studies are generally consistent with the mRNA distribution pattern (Neumaier et al., 2001; Varnas et al., 2004), which suggests predominant somatodendritic localisation. Since its discovery, a physiological role for $5-\mathrm{HT}_{7}$ receptors has been firmly established in the regulation of circadian rhythm, sleep, and mood (Hedlund, 2009).

As with the $5-\mathrm{HT}_{6}$ receptors, it was quickly noticed that several antidepressants (Monsma et al., 1993, Mullins et al., 1999) and antipsychotics (Roth et al., 1994) have high affinity for the $5-\mathrm{HT}_{7}$ receptor, leading to much subsequent research in its antidepressant effects. One preclinical study in the rat showed that several antidepressants, both tricyclics and SSRIs, induce c-fos expression in a way consistent with $5-\mathrm{HT}_{7}$ receptor activation within the suprachiasmatic nucleus, and that chronic antidepressant drug treatment leads to a down-regulation of $5-\mathrm{HT}_{7}$ receptor binding (Mullins et al., 1999). Preclinical studies also show an antidepressant-like and anxiolytic effect of the 5- $\mathrm{HT}_{7}$ receptor antagonist SB 269970 in rodents (Wesolowska et al., 2006) as well as a synergistic interaction between subefficacious doses of this agent and 
antidepressants, leading to reduced immobility in both the forced swim test and the tail suspension test (Bonaventure et al., 2007; Wesolowska et al., 2007). In addition, the genetic and pharmacological inactivation of $5-\mathrm{HT}_{7}$ receptors partly reversed phencyclidine-induced deficits of pre-pulse inhibition, an animal model of antipsychotic activity (Semenova et al., 2008). In this respect, it should also be noted that the atypical antipsychotic aripiprazole, which has high affinity for the $5-\mathrm{HT}_{7}$ receptor is sometimes used to augment the effect of traditional antidepressants (Berman et al., 2009). Similarly, a recent study has suggested that the antidepressant effects of amisulpride are due to its action at 5- $\mathrm{HT}_{7}$ receptors (Abbas et al., 2009). Overall, the $5-\mathrm{HT}_{7}$ receptor is now being considered a new promising target in antidepressant drug development (Stahl, 2010).

\section{Conclusions and implications for drug development}

Despite new advances in the antidepressant field implicating glutamatergic mechanisms (Zarate et al., 2006), it is likely that the development of new antidepressant drugs in upcoming years will still be based on the monoamine systems. In particular, the serotonergic system is closely involved in the aetiology of depression and provides a rich opportunity for developing compounds with multiple and complementary modes of action. The literature review indicates that: 1) Presynaptic 5- $\mathrm{HT}_{1 \mathrm{~A}}$ and $5-\mathrm{HT}_{1 \mathrm{~B}}$ autoreceptors play a major detrimental role in antidepressant treatments, whereas the stimulation of postsynaptic $5-\mathrm{HT}_{1 \mathrm{~A}}$ receptors in corticolimbic networks is beneficial for the antidepressant action; 2) Blockade of 5- $\mathrm{HT}_{2 \mathrm{~A} / 2 \mathrm{C}}$ receptors improves the actions of SSRIs, whereas $5-\mathrm{HT}_{2 \mathrm{~B}}$ receptor activation enhances serotonergic activity and shows antidepressant-like activity in rodents (yet this observation requires further confirmation); 3) $5-\mathrm{HT}_{3}$ receptor blockade can augment the antidepressant action of SERT inhibition; 4) $5-\mathrm{HT}_{4}$ receptor activation appears to have antidepressant effects on its own and may augment SSRI effects; and 5) Blockade of 5- $\mathrm{HT}_{6}$ and 5- $\mathrm{HT}_{7}$ receptors may also improve the antidepressant effects of SERT inhibition. 
Given the network, cellular and neurochemical complexity of the 5-HT system, its possible redundancies in terms of signalling pathways and the sometimes opposite role of some pre- and postsynaptic receptors (e.g. 5- $\mathrm{HT}_{1 \mathrm{~A}}$ ), it seems clear that drugs acting on a single receptor are unlikely to overcome the limitations of SSRIs, although new molecular approaches with cellular specificity, such as siRNA strategies, may perhaps overcome the limitations of drugs, which often do not discriminate between the same receptors expressed in different cellular phenotypes or brain regions. Therefore, it is likely that future antidepressant drugs overcoming the limitations of SSRIs and SNRIs will be developed on the basis of SERT inhibition (and perhaps NET inhibition) plus additional pharmacological activities at pre- and/or postsynaptic receptors. On the one hand, these activities should prevent the several 5-HT cell-based and networkbased negative feedback mechanisms that limit presynaptic serotonergic activity. This may include the selective reduction of $5-\mathrm{HT}_{1 \mathrm{~A}}$ and/or $5-\mathrm{HT}_{1 \mathrm{~B}}$ autoreceptor function plus the blockade of some postsynaptic receptors present in GABAergic neurons (5- $\mathrm{HT}_{3}$ and perhaps others) involved in the local and distal inhibition of serotonergic activity. On the other hand, since postsynaptic receptors play different and often opposing roles in experimental tests of depression, new compounds should show different postsynaptic activities, being agonists at certain receptors, such as $5-\mathrm{HT}_{1 \mathrm{~A}}$ (yet with the aforementioned problem of suppressing presynaptic 5-HT activity) and 5- $\mathrm{HT}_{4}$ receptors and antagonists at other excitatory 5-HT receptors (e.g. 5- $\mathrm{HT}_{2 \mathrm{~A} / 2 \mathrm{C}} 5-\mathrm{HT}_{6}, 5-\mathrm{HT}_{7}$ ). Indeed, drugs showing all these pharmacological activities are technically unfeasible and might present many side effects due to their large number of pharmacological activities. However, it should be noted that recently developed compounds such as vilazodone and vortioxetine (Lu AA21004) go along these lines, as they add a partial $5-\mathrm{HT}_{1 \mathrm{~A}}$ agonist activity to SERT inhibition, mimicking the pharmacological actions of the SSRI + pindolol combination (vortioxetine shows additional activities at other 5-HT 
receptors; see above). Future drugs may incorporate new activities in parallel with a better knowledge of the $5-\mathrm{HT}$ system.

The antidepressant properties of 5-HT-enhancing drugs and of agonists/antagonists of 5-HT receptors derive from their modulation of corticolimbic networks whose function is altered in major depression, thereby normalising neurotransmitter function (glutamate, GABA) in these circuits. This effect may also be evoked by other monoamines, such as NE and DA, whose transporters are targeted by other antidepressant drugs (acetylcholine may also participate by improving cognitive symptoms). 5-HT exerts a widespread and complex regulation of the function of monoaminergic neurotransmission (Fink and Gothert, 2007) which is often reciprocal (e.g. serotonergic activity is tonically dependent on an $\alpha_{1}$-adrenergic input). As an example, activation of $5-\mathrm{HT}_{1 \mathrm{~A}}$ receptors increases the release of $\mathrm{NE}$ and $\mathrm{DA}$ in forebrain, an effect likely involving $5-\mathrm{HT}_{1 \mathrm{~A}}$ receptors in cortical pyramidal neurons projecting to the brainstem (HajosKorcsok and Sharp, 1996; Díaz-Mataix et al., 2005). On the other hand, 5- $\mathrm{HT}_{3}$ receptor blockade stimulates acetylcholine release (Barnes et al., 1989). Thus, changes in serotonergic activity evoke a series of parallel changes of these other monoamines, which may also contribute to the clinical action of antidepressant drugs acting primarily on the 5-HT system.

Novel molecular mechanisms have been identified in the last decade that affect neurotransmitter function. Hence, microRNA are related to the pathophysiology and treatment of several CNS diseases, including depression (Mouillet-Richard et al., 2012), being also involved in the regulation of serotonergic neurotransmission (Millan et al., 2011). In particular, microRNA16 has been shown to modulate SERT expression and to be modulated by chronic antidepressant treatments (Baudry et al., 2010) and mediates the enhancement of hippocampal neurogenesis by SSRI (Launay et al., 2011). Moreover, small interference RNA (siRNA) has been used to modulate the expression of serotonergic genes and to evoke antidepressant-like 
effects in rodents. Hence, the reduction of the expression of SERT increased serotonergic function and reduced the immobility in the forced-swim test (Thakker et al., 2005). Likewise, the selective reduction of $5-\mathrm{HT}_{1 \mathrm{~A}}$ autoreceptor expression by a modified siRNA selectively targeting raphe 5-HT neurons (Bortolozzi et al., 2012) or by the local application of unmodified siRNA into the dorsal raphe (Ferrés-Coy et al., 2012) enhanced serotonergic function and evoked strong antidepressant-like effects. Overall, the use of these molecular strategies may add to pharmacological approaches in the search for new antidepressant treatments overcoming the limitations of existing drugs.

In conclusion, the 5-HT system offers a large number of possibilities to develop new antidepressant treatments, based on combinations of different pharmacological activities in addition to SERT inhibition. Yet, these activities need to be carefully selected to overcome selflimiting mechanisms of serotonergic activity as well as a selective activation or blockade of relevant postsynaptic receptors. In addition to drugs, new therapeutic approaches based on molecular approaches achieving cellular specificity may be possible.

\section{Acknowledgements}

Supported by the Innovative Medicine Initiative Joint Undertaking under grant agreement $\mathrm{n}^{\circ}$ 115008, of which resources are composed of EFPIA in-kind contribution and financial contribution from the European Union's Seventh Framework Programme (FP7/2007-2013) and by grant SAF 2012- 35183 from the Ministerio de Economía y Competitividad. Support from the Generalitat de Catalunya (2009-SGR220) and the Centro de Investigación Biomédica en Red de Salud Mental (CIBERSAM) is also acknowledged. 


\section{Conflict of interest}

FA has received consulting and educational honoraria on antidepressant drugs from Eli Lilly and Lundbeck A/S. FA has also been PI from a research contract with Pierre Fabre on 5-HT $1 \mathrm{~A}$ agonists and with nLife Therapeutics on siRNA modulation of serotonergic function. 


\section{References}

1. ABbAS, A. I., HEDlUnd, P. B., HUANG, X. P., TRAN, T. B., MELTZER, H. Y. \& ROTH, B. L. 2009. Amisulpride is a potent 5-HT7 antagonist: relevance for antidepressant actions in vivo. Psychopharmacology (Berl), 205, 119-28.

2. ABRAMOWSKI, D., RIGO, M., DUC, D., HOYER, D. \& STAUFENBIEL, M. 1995. Localization of the 5-hydroxytryptamine2C receptor protein in human and rat brain using specific antisera. Neuropharmacology, 34, 1635-45.

3. ADELL, A. \& ARTIGAS, F. 1991. Differential effects of clomipramine given locally or systemically on extracellular 5-hydroxytryptamine in raphe nuclei and frontal cortex. An in vivo brain microdialysis study. Naunyn Schmiedebergs Arch Pharmacol, 343, 237-44.

4. ADELL, A., CARCELLER, A. \& ARTIGAS, F. 1993. In vivo brain dialysis study of the somatodendritic release of serotonin in the Raphe nuclei of the rat: effects of 8-hydroxy2-(di-n-propylamino)tetralin. J Neurochem, 60, 1673-81.

5. ADELL, A., CASANOVAS, J. M. \& ARTIGAS, F. 1997. Comparative study in the rat of the actions of different types of stress on the release of 5-HT in raphe nuclei and forebrain areas. Neuropharmacology, 36, 735-41.

6. AlvareZ, E., PEREZ, V., DRAGheim, M., LOFT, H. \& ARTIGAS, F. 2012. A doubleblind, randomized, placebo-controlled, active reference study of Lu AA21004 in patients with major depressive disorder. Int J Neuropsychopharmacol, 15:589-600.

7. AmARgos-BOSCh, M., BORTOlOZZI, A., PUIG, M. V., SERRATS, J., ADELL, A., CELADA, P., TOTH, M., MENGOD, G. \& ARTIGAS, F. 2004. Co-expression and in vivo interaction of serotonin $1 \mathrm{~A}$ and serotonin2A receptors in pyramidal neurons of prefrontal cortex. Cereb Cortex, 14, 281-99.

8. ANDLIN-SOBOCKI, P., JONSSON, B., WITTCHEN, H. U. \& OLESEN, J. 2005. Cost of disorders of the brain in Europe. Eur J Neurol, 12 Suppl 1, 1-27. 
9. ANGel, I., SChOEMAKeR, H., PROUTEAU, M., GARREAU, M. \& LANGER, S. Z. 1993. Litoxetine: a selective 5-HT uptake inhibitor with concomitant 5-HT3 receptor antagonist and antiemetic properties. Eur J Pharmacol, 232, 139-45.

10. ARTIGAS, F. 1993. 5-HT and antidepressants: new views from microdialysis studies. Trends Pharmacol Sci, 14, 262.

11. ARTIGAS, F., ADELL, A. \& CELADA, P. 2006. Pindolol augmentation of antidepressant response. Curr Drug Targets, 7, 139-47.

12. ARtigas, F., CeladA, P., LARUelle, M., \& ADELL, A. 2001. How does pindol improve antidepressant action? Trends Pharmacol Sci, 22, 224-8.

13. ARTIGAS, F., PEREZ, V. \& ALVAREZ, E. 1994. Pindolol induces a rapid improvement of depressed patients treated with serotonin reuptake inhibitors. Arch Gen Psychiatry, $51,248-51$.

14. ARTIGAS, F., ROMERO, L., DE MONTIGNY, C. \& BLIER, P. 1996. Acceleration of the effect of selected antidepressant drugs in major depression by 5-HT1A antagonists. Trends Neurosci, 19, 378-83.

15. ASBERG, M., TRASKMAN, L. \& THOREN, P. 1976. 5-HIAA in the cerebrospinal fluid. A biochemical suicide predictor? Arch Gen Psychiatry, 33, 1193-7.

16. AZMITIA, E. C. \& WHITAKER-AZMITIA, P. M. 1991. Awakening the sleeping giant: anatomy and plasticity of the brain serotonergic system. J Clin Psychiatry, 52 Suppl, 416.

17. BAGDY, E., KIRALY, I. \& HARSING, L. G., JR. 2000. Reciprocal innervation between serotonergic and GABAergic neurons in raphe nuclei of the rat. Neurochem Res, 25, 1465-73.

18. BALDWIN, D. S., LOFT, H. \& DRAGHEIM, M. 2011. A randomised, double-blind, placebo controlled, duloxetine-referenced, fixed-dose study of three dosages of Lu 
AA21004 in acute treatment of major depressive disorder (MDD). Eur Neuropsychopharmacol [in press] doi: 10.1016/j.euroneuro.2011.11.008

19. BALLESTEROS, J. \& CALLADO, L. F. 2004. Effectiveness of pindolol plus serotonin uptake inhibitors in depression: a meta-analysis of early and late outcomes from randomised controlled trials. J Affect Disord, 79, 137-47.

20. BARNeS, N. M., COSTALL, B., GE, J., KELLY, M. E. \& NAYLOR, R. J. 1992. The interaction of $\mathrm{R}(+)$ - and $\mathrm{S}(-)$-zacopride with PCPA to modify rodent aversive behaviour. Eur J Pharmacol, 218, 15-25.

21. BARNES, N. M. \& SHARP, T. 1999. A review of central 5-HT receptors and their function. Neuropharmacology, 38, 1083-152.

22. BAUDRY, A., S. MOUILLET-RICHARD, B. SCHNEIDER, J. M. LAUNAY, AND O. KELLERMANN. 2010. miR-16 targets the serotonin transporter: a new facet for adaptive responses to antidepressants. Science 329, 1537-41.

23. BEAUDET, A. \& DESCARRIES, L. 1976. Quantitative data on serotonin nerve terminals in adult rat neocortex. Brain Res, 111, 301-9.

24. BEL, N. \& ARTIGAS, F. 1992. Fluvoxamine preferentially increases extracellular 5hydroxytryptamine in the raphe nuclei: an in vivo microdialysis study. Eur J Pharmacol, $229,101-3$

25. BEL, N. \& ARTIGAS, F. 1993. Chronic treatment with fluvoxamine increases extracellular serotonin in frontal cortex but not in raphe nuclei. Synapse, 15, 243-5.

26. BERMAN, R. M., FAVA, M., THASE, M. E., TRIVEDI, M. H., SWANINK, R., MCQUADE, R. D., CARSON, W. H., ADSON, D., TAYLOR, L., HAZEL, J. \& MARCUS, R. N. 2009. Aripiprazole augmentation in major depressive disorder: a double-blind, placebocontrolled study in patients with inadequate response to antidepressants. CNS Spectr, 14, 197-206. 
27. BERTON, O. \& NESTLER, E. J. 2006. New approaches to antidepressant drug discovery: beyond monoamines. Nat Rev Neurosci, 7, 137-51.

28. BHAGWAGAR, Z., RABINER, E. A., SARGENT, P. A., GRASBY, P. M., \& COWEN, P. J. 2004. Persistent reduction in brain serotonin1A receptor binding in recovered depressed men measured by positron emission tomography with [11C]WAY-100635. Mol Psychiatry, 9, 386-92.

29. BLIER, P. \& DE MONTIGNY, C. 1994. Current advances and trends in the treatment of depression. Trends Pharmacol Sci, 15, 220-6.

30. BLIER, P. \& WARD, N. M. 2003. Is there a role for 5-HT1A agonists in the treatment of depression? Biol Psychiatry, 53, 193-203.

31. BOLDRINI, M., UNDERWOOD, M. D., MANN, J. J., \& ARANGO, V. 2008. Serotonin-1A autoreceptor binding in the dorsal raphe nucleus of depressed suicides. J Psychiatr Res, $42,433-42$.

32. BONAVEntURE, P., GUO, H., TIAN, B., LIU, X., BITTNER, A., ROLAND, B., SALUNGA, R., MA, X. J., KAMME, F., MEURERS, B., BAKKER, M., JURZAK, M., LEYSEN, J. E. \& ERLANDER, M. G. 2002. Nuclei and subnuclei gene expression profiling in mammalian brain. Brain Res, 943, 38-47.

33. BONAVENTURE, P., KELLY, L., ALUISIO, L., SHELTON, J., LORD, B., GALICI, R., MILLER, K., ATACK, J., LOVENBERG, T. W. \& DUGOVIC, C. 2007. Selective blockade of 5-hydroxytryptamine (5-HT)7 receptors enhances 5-HT transmission, antidepressantlike behavior, and rapid eye movement sleep suppression induced by citalopram in rodents. J Pharmacol Exp Ther, 321, 690-8.

34. BONHAUS, D. W., BACH, C., DESOUZA, A., SALAZAR, F. H., MATSUOKA, B. D., ZUPPAN, P., CHAN, H. W. \& EGLEN, R. M. 1995. The pharmacology and distribution of human 5-hydroxytryptamine2B (5-HT2B) receptor gene products: comparison with 5HT2A and 5-HT2C receptors. Br J Pharmacol, 115, 622-8. 
35. BORTOlozZI, A., CASTANe, A., SEMAKOVA, J., SANTANA, N., ALVARADO, G., CORTES, R., FERRES-COY, A., FERnANDEZ, G., CARMONA, M. C., TOTH, M., PERAlES, J. C., MONTEFELTRO, A. \& ARTIGAS, F. 2011. Selective siRnA-mediated suppression of $5-\mathrm{HT}(1 \mathrm{~A})$ autoreceptors evokes strong anti-depressant-like effects. $\mathrm{Mol}$ Psychiatry. Published online ahead of print August 2, 2011; doi: 10.1038/mp.2011.92.

36. BRANCHEK, T. A. \& BLACKBURN, T. P. 2000. 5-ht6 receptors as emerging targets for drug discovery. Annu Rev Pharmacol Toxicol, 40, 319-34.

37. BRESSA, G. M., MARINI, S. \& GREGORI, S. 1987. Serotonin S2 receptors blockade and generalized anxiety disorders. A double-blind study on ritanserin and lorazepam. Int J Clin Pharmacol Res, 7, 111-9.

38. BUBAR, M. J., STUTZ, S. J. \& CUNNINGHAM, K. A. 2011. 5-HT(2C) receptors localize to dopamine and GABA neurons in the rat mesoaccumbens pathway. PLoS One, 6, e20508. doi: 10.1371/journal.pone.0020508.

39. BURNET, P. W., EASTWOOD, S. L., LACEY, K. \& HARRISON, P. J. 1995. The distribution of 5-HT1A and 5-HT2A receptor mRNA in human brain. Brain Res, 676, 15768.

40. CARPENTER, L. L., JOCIC, Z., HALL, J. M., RASMUSSEN, S. A. \& PRICE, L. H. 1999. Mirtazapine augmentation in the treatment of refractory depression. J Clin Psychiatry, $60,45-9$.

41. CARVALHO, A. F., MACHADO, J. R. \& CAVALCANTE, J. L. 2008. Augmentation strategies for treatment-resistant depression. Curr Opin Psychiatry, 22, 7-12.

42. CASANOVAS, J. M. \& ARTIGAS, F. 1996. Differential effects of ipsapirone on 5hydroxytryptamine release in the dorsal and median raphe neuronal pathways. $J$ Neurochem, 67, 1945-52. 
43. CASANOVAS, J. M., LESOURD, M. \& ARTIGAS, F. 1997. The effect of the selective 5HT1A agonists alnespirone (S-20499) and 8-OH-DPAT on extracellular 5hydroxytryptamine in different regions of rat brain. $\mathrm{Br} \mathrm{J}$ Pharmacol, 122, 733-41.

44. CASTRO, M. E., PASCUAL, J., ROMON, T., BERCIANO, J., FIGOLS, J. \& PAZOS, A. 1998. 5-HT1B receptor binding in degenerative movement disorders. Brain Res, 790, 323-8.

45. CELADA, P. \& ARTIGAS, F. 1993. Monoamine oxidase inhibitors increase preferentially extracellular 5-hydroxytryptamine in the midbrain raphe nuclei. A brain microdialysis study in the awake rat. Naunyn Schmiedebergs Arch Pharmacol, 347, 583-90.

46. CElAdA, P., PUIG, M., AMARgos-BOSCH, M., ADELL, A. \& ARTIGAS, F. 2004. The therapeutic role of 5-HT1A and 5-HT2A receptors in depression. J Psychiatry Neurosci, 29, 252-65.

47. CELADA, P., PUIG, M. V., CASANOVAS, J. M., GUILLAZO, G. \& ARTIGAS, F. 2001. Control of dorsal raphe serotonergic neurons by the medial prefrontal cortex: Involvement of serotonin-1A, GABA(A), and glutamate receptors. J Neurosci, 21, 991729.

48. CHENU, F., DAVID, D. J., LEROUX-NICOLLET, I., LE MAITRE, E., GARDIER, A. M. \& BOURIN, M. 2008. Serotonin1B heteroreceptor activation induces an antidepressant-like effect in mice with an alteration of the serotonergic system. J Psychiatry Neurosci, 33, $541-50$

49. CLENET, F., DE VOS, A. \& BOURIN, M. 2001. Involvement of 5-HT(2C) receptors in the anti-immobility effects of antidepressants in the forced swimming test in mice. Eur Neuropsychopharmacol, 11, 145-52.

50. CONDUCTIER, G., DUSTICIER, N., LUCAS, G., COTE, F., DEBONNEL, G., DASZUTA, A., DUMUIS, A., NIEOUllon, A., HEN, R., BOCKAeRT, J. \& COMPAN, V. 2006. 
Adaptive changes in serotonin neurons of the raphe nuclei in 5-HT(4) receptor knock-out mouse. Eur J Neurosci, 24, 1053-62.

51. COSTALL, B., DOMENEY, A. M., KELLY, M. E. \& NAYLOR, R. J. 1993. The effects of 5-HT3 receptor antagonists in models of dependency and withdrawal. Alcohol Alcohol Suppl, 2, 269-73.

52. CREMERS, T. I., GIORGETTI, M., BOSKER, F. J., HOGG, S., ARNT, J., MORK, A., HONIG, G., BOGESO, K. P., WESTERINK, B. H., DEN BOER, H., WIKSTROM, H. V. \& TECOTT, L. H. 2004. Inactivation of 5-HT(2C) receptors potentiates consequences of serotonin reuptake blockade. Neuropsychopharmacology, 29, 1782-9.

53. CREMERS, T. I., REA, K., BOSKER, F. J., WIKSTROM, H. V., HOGG, S., MORK, A. \& WESTERINK, B. H. 2007. Augmentation of SSRI effects on serotonin by 5-HT2C antagonists: mechanistic studies. Neuropsychopharmacology, 32, 1550-7.

54. CRYAN, J. F., \&LUCKI, I. 2000. Antidepressant-like behavioral effects mediated by 5hydroxytryptamine2C receptors. J Pharmacol Exp Ther, 295, 1120-6.

55. CRYAN, J. F., VALENTINO, R. J. \& LUCKI, I. 2005. Assessing substrates underlying the behavioral effects of antidepressants using the modified rat forced swimming test. Neurosci Biobehav Rev, 29, 547-69.

56. DAWSON, L. A. \& LI, P. 2003. Effects of 5-HT(6) receptor blockade on the neurochemical outcome of antidepressant treatment in the frontal cortex of the rat. $J$ Neural Transm, 110, 577-90.

57. DE ALMEIDA, J. \& MENGOD, G. 2007. Quantitative analysis of glutamatergic and GABAergic neurons expressing $5-\mathrm{HT}(2 \mathrm{~A})$ receptors in human and monkey prefrontal cortex. J Neurochem, 103, 475-86.

58. DE BOER, S. F. \& KOOLHAAS, J. M. 2005. 5-HT1A and 5-HT1B receptor agonists and aggression: a pharmacological challenge of the serotonin deficiency hypothesis. Eur $\mathrm{J}$ Pharmacol, 526, 125-39. 
59. DE FOUBERT, G., O'NEILL, M. J. \& ZETTERSTROM, T. S. 2007. Acute onset by 5$\mathrm{HT}(6)$-receptor activation on rat brain brain-derived neurotrophic factor and activityregulated cytoskeletal-associated protein mRNA expression. Neuroscience, 147, 77885.

60. DElGADO, P. L., CHARNEY, D. S., PRICE, L. H., AGHAJANIAN, G. K., LANDIS, H. \& HENINGER, G. R. 1990. Serotonin function and the mechanism of antidepressant action. Reversal of antidepressant-induced remission by rapid depletion of plasma tryptophan. Arch Gen Psychiatry, 47, 411-8.

61. DEPOORTERE, R., AUCLAIR, A. L., BARDIN, L., COLPAERT, F. C., VACHER, B. \& NEWMAN-TANCREDI, A. 2010. F15599, a preferential post-synaptic 5-HT1A receptor agonist: activity in models of cognition in comparison with reference 5-HT1A receptor agonists. Eur Neuropsychopharmacol, 20, 641-54.

62. DIAZ-MATAIX, L., SCORZA, M. C., BORTOLOZZI, A., TOTH, M., CELADA, P., \& ARTIGAS, F. 2005. Involvement of 5-HT1A recetors in prefrontal cortex in the modulation of dopaminergic activity: role in atypical antipsychotic action. J Neurosci, $25: 10831-43$

63. DIAZ, S. L., DOLY, S., NARBOUX-NEME, N., FERNANDEZ, S., MAZOT, P., BANAS, S. M., BOUTOURLINSKY, K., MOUTKINE, I., BELMER, A., ROUMIER, A., \& MAROTEAUX, L. 2012. 5-HT2B receptors are required for serotonin-selective antidepressant actions. Mol Psychiatry, 17,154-63.

64. DREVETS, W. C., PRICE, J. L. \& FUREY, M. L. 2008. Brain structural and functional abnormalities in mood disorders: implications for neurocircuitry models of depression. Brain Struct Funct, 213, 93-118.

65. DUMAN, R. S. 2007. A silver bullet for the treatment of depression? Neuron, 55, 679-81.

66. DUMAN, R. S., HENINGER, G. R. \& NESTLER, E. J. 1997. A molecular and cellular theory of depression. Arch Gen Psychiatry, 54, 597-606. 
67. DUXON, M. S., FLANIGAN, T. P., REAVLEY, A. C., BAXTER, G. S., BLACKBURN, T. P. \& FONE, K. C. 1997. Evidence for expression of the 5-hydroxytryptamine-2B receptor protein in the rat central nervous system. Neuroscience, 76, 323-9.

68. EGELAND, M., WARNER-SCHMIDT, J., GREENGARD, P. \& SVENNINGSSON, P. 2011. Co-expression of serotonin 5-HT(1B) and 5-HT(4) receptors in p11 containing cells in cerebral cortex, hippocampus, caudate-putamen and cerebellum. Neuropharmacology, 61, 442-50.

69. EISENSAMER, B., RAMMES, G., GIMPL, G., SHAPA, M., FERRARI, U., HAPFELMEIER, G., BONDY, B., PARSONS, C., GILLING, K., ZIEGLGANSBERGER, W., HOLSBOER, F. \& RUPPRECHT, R. 2003. Antidepressants are functional antagonists at the serotonin type 3 (5-HT3) receptor. Mol Psychiatry, 8, 994-1007.

70. El MANSARI, M., SANCHEZ, C., CHOUVET, G., RENAUD, B. \& HADDJERI, N. 2005. Effects of acute and long-term administration of escitalopram and citalopram on serotonin neurotransmission: an in vivo electrophysiological study in rat brain. Neuropsychopharmacology, 30, 1269-77.

71. ENGLEMAN, E. A., RODD, Z. A., BELL, R. L. \& MURPHY, J. M. 2008. The role of 5HT3 receptors in drug abuse and as a target for pharmacotherapy. CNS Neurol Disord Drug Targets, 7, 454-67.

72. FAN, P. 1994. Facilitation of 5-hydroxytryptamine3 receptor desensitization by fluoxetine. Neuroscience, 62, 515-22.

73. FERRER, A. \& ARTIGAS, F. 1994. Effects of single and chronic treatment with tranylcypromine on extracellular serotonin in rat brain. Eur J Pharmacol, 263, 227-34.

74. FERRES-COY, A., N. SANTANA, A. CASTANE, R. CORTES, M. C. CARMONA, M. TOTH, A. MONTEFELTRO, F. ARTIGAS, AND A. BORTOLOZZI. 2012. Acute 5-HT(1A) autoreceptor knockdown increases antidepressant responses and serotonin release in stressful conditions. Psychopharmacology Epub. July 21. 
75. FINK, K., SCHMITZ, V., BOING, C. \& GOTHERT, M. 1995. Stimulation of serotonin release in the rat brain cortex by activation of ionotropic glutamate receptors and its modulation via alpha 2-heteroreceptors. Naunyn Schmiedebergs Arch Pharmacol, 352, 394-401.

76. FINK, K. B. \& GOTHERT, M. 2007. 5-HT receptor regulation of neurotransmitter release. Pharmacol Rev, 59, 360-417.

77. GABBOtT, P. L. A., WARner, T. A., JAYS, P. R. L., SAlWAY, P., \& BUSBY, S. J. 2005. Prefrontal cortex in the rat: projections to subcortical autonomic, motor, and limbic centers. J Comp Neurol, 492, 145-77.

78. GERVASONI, D., PEYRON, C., RAMPON, C., BARBAGLI, B., CHOUVET, G., URBAIN, N., FORT, P. \& LUPPI, P.-H. 2000. Role and origin of the GABAergic innervation of dorsal raphe serotonergic neurons. J Neurosci, 20, 4217-25.

79. GOBERT, A., DEKEYNE, A. \& MILLAN, M. J. 2000a. The ability of WAY100,635 to potentiate the neurochemical and functional actions of fluoxetine is enhanced by coadministration of SB224,289, but not BRL15572. Neuropharmacology, 39, 1608-16.

80. GOBERT, A., RIVET, J.-M., CISTARELLI, L. \& MILLAN, M. J. 1997. Potentiation of the fluoxetine-induced increase in dialysate levels of serotonin $(5-\mathrm{HT})$ in the frontal cortex of freely moving rats by combined blockade of 5-HT1A and 5-HT1B receptors with WAY 100,635 and GR 127,935. J Neurochem, 68, 1159-63.

81. GOBERT, A., RIVET, J.-M., LEJEUNE, F., NEWMAN-TANCREDI, A., ADHUMEAUAUCLAIR, A., NICOLAS, J. P., CISTARELLI, L., MELON, C. \& MILLAN, M. J. 2000b. Serotonin(2C) receptors tonically suppress the activity of mesocortical dopaminergic and adrenergic, but not serotonergic, pathways: a combined dialysis and electrophysiological analysis in the rat. Synapse, 36, 205-21.

82. GRAY, J. A. \& ROTH, B. L. 2001. Paradoxical trafficking and regulation of 5-HT(2A) receptors by agonists and antagonists. Brain Res Bull, 56, 441-51. 
83. GUREVICH, I., TAMIR, H., ARANGO, V., DWORK, A. J., MANN, J. J., \& SCHMAUSS, C. 2002. Altered editing of serotonin $2 \mathrm{C}$ receptor pre-mRNA in the prefrontal cortex of depressed suicide victims. Neuro,. 34, 349-56.

84. HADDJERI, N., BLIER, P. \& DE MONTIGNY, C. 1998. Long-term antidepressant treatments result in a tonic activation of forebrain 5-HT1A receptors. J Neurosci, 18, 10150-6.

85. HAJOS-KORCSOK, E., \& SHARP, T. 1996. 8-OH-DPAT-induced release of hippocampal noradrenaline in vivo: evidence for a role of both $5-\mathrm{HT} 1 \mathrm{~A}$ and dopamine D1 receptors. Eur J Pharmacol, 314, 285-91.

86. HARMER, C. J., REID, C. B., RAY, M. K., GOODWIN, G. M. \& COWEN, P. J. 2006. $5 \mathrm{HT}(3)$ antagonism abolishes the emotion potentiated startle effect in humans. Psychopharmacology (Berl), 186, 18-24.

87. HARRO, J. \& ORELAND, L. 2001. Depression as a spreading adjustment disorder of monoaminergic neurons: a case for primary implication of the locus coeruleus. Brain Res Rev, 38, 79-128.

88. HEAL, D. J., SMITH, S. L., FISAS, A., CODONY, X. \& BUSCHMANN, H. 2008. Selective 5-HT6 receptor ligands: progress in the development of a novel pharmacological approach to the treatment of obesity and related metabolic disorders. Pharmacol Ther, 117, 207-31.

89. HEDLUND, P. B. 2009. The 5-HT7 receptor and disorders of the nervous system: an overview. Psychopharmacology (Berl), 206, 345-54.

90. HEDLUND, P. B. \& SUTCLIFFE, J. G. 2004. Functional, molecular and pharmacological advances in 5-HT7 receptor research. Trends Pharmacol Sci, 25, 481-6.

91. HERRSTEDT, J. 1996. New perspectives in antiemetic treatment. Support Care Cancer, 4, 416-9. 
92. HERVAS, I., QUEIROZ, C. M., ADELL, A. \& ARTIGAS, F. 2000. Role of uptake inhibition and autoreceptor activation in the control of 5-HT release in the frontal cortex and dorsal hippocampus of the rat. Br J Pharmacol, 130, 160-6.

93. HERVAS, I., VILARO, M. T., ROMERO, L., SCORZA, M. C., MENGOD, G. \& ARTIGAS, F. 2001. Desensitization of 5-HT(1A) autoreceptors by a low chronic fluoxetine dose effect of the concurrent administration of WAY-100635. Neuropsychopharmacology, 24, 11-20.

94. HJORTH, S. \& SHARP, T. 1991. Effect of the 5-HT1A receptor agonist 8-OH-DPAT on the release of $5-\mathrm{HT}$ in dorsal and median raphe-innervated rat brain regions as measured by in vivo microdialysis. Life Sci, 48, 1779-86.

95. HOYER, D., CLARKE, D. E., FOZARD, J. R., HARTIG, P. R., MARTIN, G. R., MYLECHARANE, E. J., SAXENA, P. R. \& HUMPHREY, P. P. 1994. International Union of Pharmacology classification of receptors for 5-hydroxytryptamine (Serotonin). Pharmacol Rev, 46, 157-203.

96. HUANG, Y. Y., OQUENDO, M. A., Harkavy FRIEDMAN, J. M., GREENHILL, L. L., BRODSKY, B., MALONE, K. M., KHAIT, V. \& MANN, J. J. 2003. Substance abuse disorder and major depression are associated with the human 5-HT1B receptor gene (HTR1B) G861C polymorphism. Neuropsychopharmacology, 28, 163-9.

97. INVERNIZZI, R. W., PIERUCCI, M., CALCAGNO, E., DIGIOVANNI, G., DIMATTEO, V., BENIGNO, A., \& ESPOSITO, E. 2007. Selective activation of 5-HT2C receptors stimulates GABA-ergic function in the rat substantia nigra pars reticulata: a combined in vivo electrophysiological and neurochemical study. Neuroscience, 144, 1523-35.

98. JACOBS, B. L. \& AZMITIA, E. C. 1992. Structure and function of the brain serotonin system. Physiol Rev, 72, 165-229.

99. JACOBS, B. L., VAN PRAAG, H. \& GAGE, F. H. 2000. Adult brain neurogenesis and psychiatry: a novel theory of depression. Mol Psychiatry, 5, 262-9. 
100. KELLEY, S. P., BRATT, A. M. \& HODGE, C. W. 2003. Targeted gene deletion of the 5-HT3A receptor subunit produces an anxiolytic phenotype in mice. Eur $\mathrm{J}$ Pharmacol, 461, 19-25.

101. KENNEDY, S. H., P. GIACOBBE, S. J. RIZVI, F. M. PLACENZA, Y. NISHIKAWA, H. S. MAYBERG, AND A. M. LOZANO. 2011. Deep brain stimulation for treatment-resistant depression: follow-up after 3 to 6 years. Am.J.Psychiatry 168, 50210.

102. KESSLER, R. C., CHIU, W. T., DEMLER, O., MERIKANGAS, K. R. \& WALTERS, E. E. 2005. Prevalence, severity, and comorbidity of 12-month DSM-IV disorders in the National Comorbidity Survey Replication. Arch Gen Psychiatry, 62, 61727.

103. KLEIN, M. T., DUKAT, M., GLENNON, R. A. \& TEITLER, M. 2011. Toward selective drug development for the human 5-hydroxytryptamine $1 \mathrm{E}$ receptor: a comparison of 5-hydroxytryptamine $1 \mathrm{E}$ and $1 \mathrm{~F}$ receptor structure-affinity relationships. $\mathrm{J}$ Pharmacol Exp Ther, 337, 860-7.

104. KOBAYASHI, K., IKEDA, Y., HANEDA, E. \& SUZUKI, H. 2008. Chronic fluoxetine bidirectionally modulates potentiating effects of serotonin on the hippocampal mossy fiber synaptic transmission. J Neurosci, 28, 6272-80.

105. KOS, T., POPIK, P., PIETRASZEK, M., SCHAFER, D., DANYSZ, W., DRAVOLINA, O., BLOKHINA, E., GALANKIN, T. \& BESPALOV, A. Y. 2006. Effect of 5HT3 receptor antagonist MDL 72222 on behaviors induced by ketamine in rats and mice. Eur Neuropsychopharmacol, 16, 297-310.

106. KURSAR, J. D., NELSON, D. L., WAINSCOTT, D. B. \& BAEZ, M. 1994. Molecular cloning, functional expression, and mRNA tissue distribution of the human 5hydroxytryptamine2B receptor. Mol Pharmacol, 46, 227-34. 
107. LAUNAY, J. M., S. MOUILLET-RICHARD, A. BAUDRY, M. PIETRI, AND O. KELLERMANN. 2011. Raphe-mediated signals control the hippocampal response to SRI antidepressants via miR-16. Transl.Psychiatry 1, Epub Nov. 22.

108. LEMONDE, S., TURECKI, G., BAKISH, D., HRDINA, P. D., BOWN, C. D., SEQUEIRA, A., KUSHWAHA, N., MORRIS, S. J., BASAK, A., OU, X.-M., \& ALBERT, P. R. 2003. Impaired repression at a 5-hydroxytryptamine $1 \mathrm{~A}$ receptor gene polymorphism associated with major depression and suicide. J Neurosci, 23, 8788-99.

109. LIU, S., BUBAR, M. J., LANFRANCO, M. F., HILLMAN, G. R. \& CUNNINGHAM, K. A. 2007. Serotonin2C receptor localization in GABA neurons of the rat medial prefrontal cortex: implications for understanding the neurobiology of addiction. Neuroscience, 146, 1677-88.

110. LLADO-PELFORT, L., ASSIE, M. B., NEWMAN-TANCREDI, A., ARTIGAS, F. \& CELADA, P. 2010. Preferential in vivo action of F15599, a novel 5-HT(1A) receptor agonist, at postsynaptic 5-HT(1A) receptors. Br J Pharmacol, 160, 1929-40.

111. LOPEZ-GIMENEZ, J. F., MENGOD, G., PALACIOS, J. M. \& VILARO, M. T. 2001a. Regional distribution and cellular localization of 5-HT2C receptor mRNA in monkey brain: comparison with $[3 \mathrm{H}]$ mesulergine binding sites and choline acetyltransferase mRNA. Synapse, 42, 12-26.

112. LOPEZ-GIMENEZ, J. F., VILARO, M. T., PALACIOS, J. M. \& MENGOD, G. 2001b. Mapping of 5-HT2A receptors and their mRNA in monkey brain: [3H]MDL100,907 autoradiography and in situ hybridization studies. J Comp Neurol, 429, $571-89$.

113. LOWTHER, S., KATONA, C. L., CROMPTON, M. R. \& HORTON, R. W. 1997. 5HT1D and 5-HT1E/1F binding sites in depressed suicides: increased 5-HT1D binding in globus pallidus but not cortex. Mol Psychiatry, 2, 314-21. 
114. LUCAS, G., COMPAN, V., ChARNAY, Y., NEVE, R. L., NESTLER, E. J., BOCKAERT, J., BARROT, M. \& DEBONNEL, G. 2005. Frontocortical 5-HT4 receptors exert positive feedback on serotonergic activity: viral transfections, subacute and chronic treatments with 5-HT4 agonists. Biol Psychiatry, 57, 918-25.

115. LUCAS, G., RYMAR, V. V., DU, J., MNIE-FILALI, O., BISGAARD, C., MANTA, S., LAMBAS-SENAS, L., WIBORG, O., HADDJERI, N., PINEYRO, G., SADIKOT, A. F. \& DEBONNEL, G. 2007. Serotonin(4) (5-HT(4)) receptor agonists are putative antidepressants with a rapid onset of action. Neuron, 55, 712-25.

116. LUCCHELLI, A., SANTAGOSTINO-BARBONE, M. G., BARBIERI, A., CANDURA, S. M. \& TONINI, M. 1995. The interaction of antidepressant drugs with central and peripheral (enteric) 5-HT3 and 5-HT4 receptors. Br J Pharmacol, 114, 101725.

117. MAREK, G. J., CARPENTER, L. L., MCDOUGLE, C. J. \& PRICE, L. H. 2003. Synergistic action of 5-HT2A antagonists and selective serotonin reuptake inhibitors in neuropsychiatric disorders. Neuropsychopharmacology, 28, 402-12.

118. MARNER, L., GILLINGS, N., MADSEN, K., ERRITZOE, D., BAARE, W. F., SVARER, C., HASSELBALCH, S. G. \& KNUDSEN, G. M. 2010. Brain imaging of serotonin 4 receptors in humans with [11C]SB207145-PET. Neuroimage, 50, 855-61.

119. MARTIN, P., GOZLAN, H., \& PUECH, A. J. 1992. 5-HT3 receptor antagonists reverse helpless behaviour in rats. Eur J Pharmacol, 212, 73-8.

120. MARTIN-RUIZ, R., PUIG, M. V., CELADA, P., SHAPIRO, D. A., ROTH, B. L., MENGOD, G. \& ARTIGAS, F. 2001a. Control of serotonergic function in medial prefrontal cortex by serotonin-2A receptors through a glutamate-dependent mechanism. J Neurosci, 21, 9856-66. 
121. MARTIN-RUIZ, R. \& UGEDO, L. 2001. Electrophysiological evidence for postsynaptic 5-HT(1A) receptor control of dorsal raphe 5-HT neurones. Neuropharmacology, 41, 72-8.

122. MARTIN-RUIZ, R., UGEDO, L., HONRUBIA, M. A., MENGOD, G. \& ARTIGAS, F. 2001b. Control of serotonergic neurons in rat brain by dopaminergic receptors outside the dorsal raphe nucleus. J Neurochem, 77, 762-75.

123. MARTINEZ, D., HWANG, D., MAWLAWI, O., SLIFSTEIN, M., KENT, J., SIMPSON, N., PARSEY, R. V., HASHIMOTO, T., HUANG, Y., SHINN, A., VAN heertum, R., ABi-dargham, A., CAltabiano, S., maliziA, A., COWley, H., MANN, J. J. \& LARUELLE, M. 2001. Differential occupancy of somatodendritic and postsynaptic $5 \mathrm{HT}(1 \mathrm{~A})$ receptors by pindolol: a dose-occupancy study with [11C]WAY 100635 and positron emission tomography in humans. Neuropsychopharmacology, 24, 209-29.

124. MAYBERG, H. S., A. M. LOZANO, V. VOON, H. E. MCNEELY, D. SEMINOWICZ, C. HAMANI, J. M. SCHWALB, AND S. H. KENNEDY. 2005. Deep brain stimulation for treatment-resistant depression. Neuron 45, 651-60.

125. MELTZER, H. Y., LI, Z., KANEDA, Y. \& ICHIKAWA, J. 2003. Serotonin receptors: their key role in drugs to treat schizophrenia. Prog Neuropsychopharmacol Biol Psychiatry, 27, 1159-72.

126. MILLAN, M. J. 2005. Serotonin 5-HT2C receptors as a target for the treatment of depressive and anxious states: focus on novel therapeutic strategies. Therapie, 60, 44160.

127. MILLAN, M. J. 2011. MicroRNA in the regulation and expression of serotonergic transmission in the brain and other tissues. Curr.Opin.Pharmacol. 11, 11-22.

128. MIQUEL, M. C., EMERIT, M. B., NOSJEAN, A., SIMON, A., RUMAJOGEE, P., BRISORGUEIL, M. J., DOUCET, E., HAMON, M. \& VERGE, D. 2002. Differential 
subcellular localization of the 5-HT3-As receptor subunit in the rat central nervous system. Eur J Neurosci, 15, 449-57.

129. MITCHELL, E. S., HOPLIGHT, B. J., LEAR, S. P. \& NEUMAIER, J. F. 2006. BGC20-761, a novel tryptamine analog, enhances memory consolidation and reverses scopolamine-induced memory deficit in social and visuospatial memory tasks through a 5-HT6 receptor-mediated mechanism. Neuropharmacology, 50, 412-20.

130. MONSMA, F. J., JR., SHEN, Y., WARD, R. P., HAMBLIN, M. W. \& SIBLEY, D. R. 1993. Cloning and expression of a novel serotonin receptor with high affinity for tricyclic psychotropic drugs. Mol Pharmacol, 43, 320-7.

131. MORALES, M. \& BLOOM, F. E. 1997. The 5-HT3 receptor is present in different subpopulations of GABAergic neurons in the rat telencephalon. J Neurosci, 17, 3157-67.

132. MORK, A., PEHRSON, A., BRENNUm, L. T., Moller NIELSEN, S. M., ZHONG, H., LASSEN, A. B., MILleR, S., WESTRICH, L., BOYLE, N. J., SANCHEZ, C., FISCHER, C. W., LIEBENBERG, N., WEGENER, G., BUNDGAARD, C., HOGG, S., BANG-ANDERSEN, B. \& STENSBOL, T. B. 2012. Pharmacological Effects of Lu AA21004: A Novel Multimodal Compound for the Treatment of Major Depressive Disorder. J Pharmacol Exp Ther, 340, 666-75.

133. MOSSNER, R., SCHMITT, A., HENNIG, T., BENNINGHOFF, J., GERLACH, M., RIEDERER, P., DECKERT, J. \& LESCH, K. P. 2004. Quantitation of 5HT3 receptors in forebrain of serotonin transporter deficient mice. J Neural Transm, 111, 27-35.

134. MOUILLET-RICHARD, S., A. BAUDRY, J. M. LAUNAY, AND O. KELLERMANN. 2012. MicroRNAs and depression. Neurobiol.Dis. 46, 272-8.

135. MULLINS, U. L., GIANUTSOS, G. \& EISON, A. S. 1999. Effects of antidepressants on 5-HT7 receptor regulation in the rat hypothalamus. Neuropsychopharmacology, 21, 352-67. 
136. NAKAGAWA, Y., ISHIMA, T. \& TAKASHIMA, T. 1998. The 5-HT3 receptor agonist attenuates the action of antidepressants in the forced swim test in rats. Brain Res, 786, 189-93.

137. NARANJO, C. A. \& BREMNER, K. E. 1993. Clinical pharmacology of serotoninaltering medications for decreasing alcohol consumption. Alcohol Alcohol Suppl, 2, 2219.

138. NEBIGIL, C. G., LAUNAY, J. M., HICKEL, P., TOURNOIS, C. \& MAROTEAUX, L. 2000. 5-hydroxytryptamine 2B receptor regulates cell-cycle progression: cross-talk with tyrosine kinase pathways. Proc Natl Acad Sci U S A, 97, 2591-6.

139. NEFF, C. D., ABKEVICH, V., PACKER, J. C. L, CHEN, Y., POTTER, J., RILEY, R., DAVENPORT, C., DEGRAdO WARREN, J., JAMMULAPATI, S., BATHENA, A., CHOI. W. S., KROEger, P. E., MetZger, R. E., GUTIN, A., SKOlNICK, M. H., SHATTUCK, D., \& KATZ, D. A. 2009. Evidence for HTR1A and LHPP as interacting genetic risk factors in major depression. Mol Psychiatry, 14, 621-30.

140. NESTLER, E. J., BARROT, M., DILEONE, R. J., EISCH, A. J., GOLD, S. J. \& MONTEGGIA, L. M. 2002. Neurobiology of depression. Neuron, 34, 13-25.

141. NESTLER, E. J. \& CARLEZON, W. A., JR. 2006. The mesolimbic dopamine reward circuit in depression. Biol Psychiatry, 59, 1151-9.

142. NEUMAIER, J. F., ROOT, D. C. \& HAMBLIN, M. W. 1996. Chronic fluoxetine reduces serotonin transporter mRNA and 5-HT1B mRNA in a sequential manner in the rat dorsal raphe nucleus. Neuropsychopharmacology, 15, 515-22.

143. NEUMAIER, J. F., SEXTON, T. J., YRACHETA, J., DIAZ, A. M. \& BROWNFIELD, M. 2001. Localization of 5-HT(7) receptors in rat brain by immunocytochemistry, in situ hybridization, and agonist stimulated cFos expression. $J$ Chem Neuroanat, 21, 63-73. 
144. NIKIFORUK, A., KOS, T. \& WESOLOWSKA, A. 2011. The 5-HT6 receptor agonist EMD 386088 produces antidepressant and anxiolytic effects in rats after intrahippocampal administration. Psychopharmacology (Berl), 217, 411-8.

145. NISWENDER, C. M., HERRICK-DAVIS, K., DILLEY, G. E., MELTZER, H. Y., OVERHOLSER, J. C., STOCKMEIER, C. A., EMESON, R. B. \& SANDERS-BUSH, E. 2001. RNA editing of the human serotonin 5-HT2C receptor. Alterations in suicide and implications for serotonergic pharmacotherapy. Neuropsychopharmacology, 24, 478-91.

146. O'LeARY, O. F., BECHTHOLT, A. J., CROWLEY, J. J., VALENTINO, R. J. \& LUCKI, I. 2007. The role of noradrenergic tone in the dorsal raphe nucleus of the mouse in the acute behavioral effects of antidepressant drugs. Eur Neuropsychopharmacol, 17, 215-26.

147. OSTACHER, M. J. 2007. Comorbid alcohol and substance abuse dependence in depression: impact on the outcome of antidepressant treatment. Psychiatr Clin North Am, 30, 69-76.

148. PAGE, M. E., CRYAN, J. F., SULLIVAN, A., DALVI, A., SAUCY, B., MANNING, D.R., \& LUCKI, I. 2002. Behavioral and neurochemical effects of 5-\{4-[4(5-cyano-3indolyl)-butyl)-butyl]-1-piperizinyl\}-benzofuran-2-carboxamide (EMD 68843): a combined selective inhibitor of serotonin reuptake and 5-hydroxytryptamine $1 \mathrm{~A}$ receptor partial agonist. J Pharmacol Exp Ther, 302, 1220-8.

149. PALOMERO-GALLAGHER, N., B. A. VOGT, A. SCHLEICHER, H. S. MAYBERG, AND K. ZILLES. 2009. Receptor architecture of human cingulate cortex, evaluation of the four-region neurobiological model. Hum.Brain Mapp. 30, 2336-55.

150. PARSEY, R. V., OLVET, D. M., OQUERIDO, M. A., HUANG, Y.-Y., OGDEN, R. T., \& MANN, J. J. 2006. Higher 5-HT1A receptor binding potential during a major depressive episode predicts poor treatment response: preliminary data from a naturalistic study. Neuropsychopharmacology 31, 1745-9. 
151. PAZOS, A. \& PALACIOS, J. M. 1985. Quantitative autoradiographic mapping of serotonin receptors in the rat brain. I. Serotonin-1 receptors. Brain Res, 346, 205-30.

152. PEREZ, V., SOleR, J., PUIGDEMONT, D., ALVAREZ, E. \& ARTIGAS, F. 1999. A double-blind, randomized, placebo-controlled trial of pindolol augmentation in depressive patients resistant to serotonin reuptake inhibitors. Grup de Recerca en Trastorns Afectius. Arch Gen Psychiatry, 56, 375-9.

153. PEYRON, C., LUPPI, P.-H., FORT, P., RAMPON, C. \& JOUVET, M. 1996. Lower brainstem catecholamine afferents to the rat dorsal raphe nucleus. J Comp Neurol, 364, 402-413.

154. PITTENGER, C. \& DUMAN, R. S. 2008. Stress, depression, and neuroplasticity: a convergence of mechanisms. Neuropsychopharmacology, 33, 88-109.

155. POMPEIANO, M., PALACIOS, J. M. \& MENGOD, G. 1992. Distribution and cellular localization of mRNA coding for 5-HT1A receptor in the rat brain: correlation with receptor binding. J Neurosci, 12, 440-53.

156. PRICE, L. H., ChaRney, D. S., Delgado, P. L., GOODMAN, W. K., KRYSTAL, J. H., WOODS, S. W. \& HENINGER, G. R. 1990. Clinical studies of 5-HT function using i.v. L-tryptophan. Prog Neuropsychopharmacol Biol Psychiatry, 14, 45972.

157. PRINSSEN, E. P., COLPAERT, F. C. \& KOEK, W. 2002. 5-HT1A receptor activation and anti-cataleptic effects: high-efficacy agonists maximally inhibit haloperidolinduced catalepsy. Eur J Pharmacol, 453, 217-21.

158. PUIG, M. V., SANTANA, N., CELADA, P., MENGOD, G. \& ARTIGAS, F. 2004. In vivo excitation of GABA interneurons in the medial prefrontal cortex through $5-\mathrm{HT} 3$ receptors. Cereb Cortex, 14, 1365-75.

159. PUIGDEMONT, D., R. PEREZ-EGEA, M. J. PORTELLA, J. MOLET, J. DIEGOADELINO, A. GIRONELL, J. RADUA, B. GOMEZ-ANSON, R. RODRIGUEZ, M. SERRA, 
C. DE QuintanA, F. ARTigas, E. AlVAREZ, AND V. PEREZ. 2011. Deep brain stimulation of the subcallosal cingulate gyrus: further evidence in treatment-resistant major depression. Int.J.Neuropsychopharmacol. 1-13.Epub Jul 22

160. RABINER, E. A., WILKINS, M. R., TURKHEIMER, F., GUNN, R. N., UDO DE HAES, J., DE VRIES, M. \& GRASBY, P. M. 2002. 5-Hydroxytryptamine1A receptor occupancy by novel full antagonist 2-[4-[4-(7-chloro-2,3-dihydro-1,4-benzdioxyn-5-yl)-1piperazinyl]butyl]-1,2-benzisothiazol-3-(2H)-one-1,1-dioxide: a [11C][O-methyl-3H]-N-(2(4-(2-methoxyphenyl)-1-piperazinyl)ethyl)-N-(2-pyridinyl )cyclohexanecarboxamide trihydrochloride (WAY-100635) positron emission tomography study in humans. J Pharmacol Exp Ther, 301, 1144-50.

161. RAMMES, G., EISENSAMER, B., FERRARI, U., SHAPA, M., GIMPL, G., GILLING, K., PARSONS, C., RIERING, K., HAPFELMEIER, G., BONDY, B., ZIEGLGANSBERGER, W., HOLSBOER, F. \& RUPPRECHT, R. 2004. Antipsychotic drugs antagonize human serotonin type 3 receptor currents in a noncompetitive manner. Mol Psychiatry, 9, 846-58.

162. RAYMOND, J. R., MUKHIN, Y. V., GELASCO, A., TURNER, J., COLLINSWORTH, G., GETTYS, T. W., GREWAL, J. S. \& GARNOVSKAYA, M. N. 2001. Multiplicity of mechanisms of serotonin receptor signal transduction. Pharmacol Ther, 92, 179-212.

163. RICHARDSON-JONES, J. W., CRAIGE, C. P., GUIARD, B. P., STEPHEN, A., METZGER, K. L., KUNG, H. F., GARDIER, A. M., DRANOVSKY, A., DAVID, D. J., BECK, S. G., HEN, R. \& LEONARDO, E. D. 2010. 5-HT1A autoreceptor levels determine vulnerability to stress and response to antidepressants. Neuron, 65, 40-52.

164. ROBINSON, D. S., RICKELS, K., FEIGHNER, J., FABRE, L. F., JR., GAMMANS, R. E., SHROTRIYA, R. C., ALMS, D. R., ANDARY, J. J. \& MESSINA, M. E. 
1990. Clinical effects of the 5-HT1A partial agonists in depression: a composite analysis of buspirone in the treatment of depression. J Clin Psychopharmacol, 10, 67S-76S.

165. ROllemA, H., ClARKE, T., SPROUSE, J. S. \& SCHULZ, D. W. 1996. Combined administration of a 5-hydroxytryptamine (5-HT)1D antagonist and a 5-HT reuptake inhibitor synergistically increases $5-\mathrm{HT}$ release in guinea pig hypothalamus in vivo. J Neurochem, 67, 2204-7.

166. ROMERO, L., BEL, N., ARTIGAS, F., DE MONTIGNY, C. \& BLIER, P. 1996. Effect of pindolol on the function of pre- and postsynaptic 5-HT1A receptors: in vivo microdialysis and electrophysiological studies in the rat brain. Neuropsychopharmacology, 15, 349-60.

167. ROMERO, L., CELADA, P., MARTIN-RUIZ, R., DIAZ-MATAIX, L., MOURELLE, M., DELGADILLO, J., HERVAS, I., \& ARTIGAS, F. 2003. Modulation of serotonergic function in rat brain by VN2222, a serotonin reuptake inhibitor and 5-HT1A receptor agonist. Neuropsychopharmacology, 28, 445-56.

168. ROSSE, G. \& SCHAFFHAUSER, H. 2010. 5-HT6 receptor antagonists as potential therapeutics for cognitive impairment. Curr Top Med Chem, 10, 207-21.

169. ROTH, B. L., CRAIGO, S. C., CHOUDHARY, M. S., ULUER, A., MONSMA, F. J., JR., SHEN, Y., MELTZER, H. Y. \& SIBLEY, D. R. 1994. Binding of typical and atypical antipsychotic agents to 5-hydroxytryptamine-6 and 5-hydroxytryptamine-7 receptors. $J$ Pharmacol Exp Ther, 268, 1403-10.

170. ROY, A., DE JONG, J. \& LINNOILA, M. 1989. Cerebrospinal fluid monoamine metabolites and suicidal behavior in depressed patients. A 5-year follow-up study. Arch Gen Psychiatry, 46, 609-12.

171. RUF, B. M. \& BHAGWAGAR, Z. 2009. The 5-HT1B receptor: a novel target for the pathophysiology of depression. Curr Drug Targets, 10, 1118-38. 
172. RUSH, A. J., TRIVEDI, M. H., STEWART, J. W., ET AL. 2011. Combining medications to enhance depression outcomes (CO-MED): acute and long-term outcomes of a single-blind randomized study. Am J Psychiatry, 168, 689-701.

173. RUSH, A. J., TRIVEDI, M. H., WISNNIEWSKI S. R., ET AL. 2006. Acute and longer-term outcomes in depressed outpatients requiring one or several treatment steps: a STAR*D report. Am J Psychiatry, 163, 1905-17.

174. SANABRIA-BOHORQUEZ, S. M., BIVER, F., DAMHAUT, P., WIKLER, D., VERAART, C. \& GOLDMAN, S. 2002. Quantification of 5-HT(1A) receptors in human brain using p-MPPF kinetic modelling and PET. Eur J Nucl Med, 29, 76-81.

175. SANCHEZ, C. \& HYTTEL, J. 1994. Isolation-induced aggression in mice: effects of 5-hydroxytryptamine uptake inhibitors and involvement of postsynaptic 5-HT1A receptors. Eur J Pharmacol, 264, 241-7.

176. SANTANA, N., BORTOlOZZI, A., SERRATS, J., MENGOD, G. \& ARTIGAS, F. 2004. Expression of serotonin $1 A$ and serotonin2A receptors in pyramidal and GABAergic neurons of the rat prefrontal cortex. Cereb Cortex, 14, 1100-9.

177. SARI, Y. 2004. Serotonin 1B receptors: from protein to physiological function and behavior. Neurosci Biobehav Rev, 28, 565-82.

178. SCHREIBER, R. \& DE VRY, J. 1993. 5-HT1A receptor ligands in animal models of anxiety, impulsivity and depression: multiple mechanisms of action? Prog Neuropsychopharmacol Biol Psychiatry, 17, 87-104.

179. SCORZA, M. C., LLADO-PELFORT, L., OLLER, S., CORTES, R., Puigdemont, D., PORTEllA, M. J., PEREZ-EgeA, R., AlVAREZ, E., CELAdA, P., PEREZ, V. \& ARTIGAS, F. 2011. Preclinical and clinical characterization of the selective serotonin-1A receptor antagonist $\mathrm{DU}-125530$ for antidepressant treatment. $\mathrm{Br} \mathrm{J}$ Pharmacol. Accepted; doi: 10.1111/j.1476-5381.2011.01770.x 
180. SEMENOVA, S., GEYER, M. A., SUTCLIFFE, J. G., MARKOU, A. \& HEDLUND, P. B. 2008. Inactivation of the 5-HT(7) receptor partially blocks phencyclidine-induced disruption of prepulse inhibition. Biol Psychiatry, 63, 98-105.

181. SEMINOWICZ, D. A., MAYBERG, H. S., MCINTOSH, A. R., GOLDAPPLE, K., KENNEDY, S., SEGAL, Z., \& RAFI-TARI, S. 2004. Limbic-frontal circuitry in major depression: a path modeling metanalysis. Neuroimage, 22, 409-18.

182. SERRATS, J., MENGOD, G. \& CORTES, R. 2005. Expression of serotonin 5$\mathrm{HT} 2 \mathrm{C}$ receptors in GABAergic cells of the anterior raphe nuclei. J Chem Neuroanat, 29, 83-91.

183. SHELINE, Y. I., WANG, P. W., GADO, M. H., CSERNANSKY, J. G. \& VANNIER, M. W. 1996. Hippocampal atrophy in recurrent major depression. Proc Natl Acad Sci U S A, 93, 3908-13.

184. SHELTON, R. C., TOLLEFSON, G. D., TOHEN, M., STAHL, S., GANNON, K. S., JACOBS, T. G., BURAS, W. R., BYMASTER, F. P., ZHANG, W., SPENCER, K. A., FELDMAN, P. D., \& MELTZER, H. Y. 2001. A novel augmentation strategy for treating resistant major depression. Am J Psychiatry, 158, 131-4.

185. SHOPSIN, B., FRIEDMAN, E. \& GERSHON, S. 1976. Parachlorophenylalanine reversal of tranylcypromine effects in depressed patients. Arch Gen Psychiatry, 33, 8119.

186. SHOPSIN, B., GERSHON, S., GOLDSTEIN, M., FRIEDMAN, E. \& WILK, S. 1975. Use of synthesis inhibitors in defining a role for biogenic amines during imipramine treatment in depressed patients. Psychopharmacol Commun, 1, 239-49.

187. SMITH, K. 2011. Trillion-dollar brain drain. Nature, 478, 15.

188. SMYTHIES, J. 2005. Section V. Serotonin system. Int Rev Neurobiol, 64, 217-68. 
189. SPROUSE, J. S. \& AGHAJANIAN, G. K. 1986. (-)-Propranolol blocks the inhibition of serotonergic dorsal raphe cell firing by $5-\mathrm{HT} 1 \mathrm{~A}$ selective agonists. Eur $\mathrm{J}$ Pharmacol, 128, 295-8.

190. SPROUSE, J. S. \& AGHAJANIAN, G. K. 1987. Electrophysiological responses of serotoninergic dorsal raphe neurons to 5-HT1A and 5-HT1B agonists. Synapse, 1, 3-9.

191. STAHL, S. M. 2010. The serotonin-7 receptor as a novel therapeutic target. $J$ Clin Psychiatry, 71, 1414-5.

192. STOCKMEIER, C. A., SHAPIRO, L.A., DILLEY, G. E., KOLLI, T. N., FRIEDMAN, L., \& RAJKOWSKA, G. 1998. Increase in serotonin-1A autoreceptors in the midbrain of suicide victims with major depression—postmortem evidence for decreased serotonin activity. J Neurosci, 18, 7394-401.

193. SVENNINGSSON, P., CHERGUI, K., RACHLEFF, I., FLAJOLET, M., ZHANG, X., EL YACOUBI, M., VAUGEOIS, J. M., NOMIKOS, G. G. \& GREENGARD, P. 2006. Alterations in 5-HT1B receptor function by p11 in depression-like states. Science, 311, 77-80.

194. SVENNINGSSON, P., TZAVARA, E. T., QI, H., CARRUTHERS, R., WITKIN, J. M., NOMIKOS, G. G. \& GREENGARD, P. 2007. Biochemical and behavioral evidence for antidepressant-like effects of 5-HT6 receptor stimulation. J Neurosci, 27, 4201-9.

195. TATARCZYNSKA, E., KLODZINSKA, A., STACHOWICZ, K. \& CHOJNACKAWOJCIK, E. 2004. Effect of combined administration of 5-HT1A or 5-HT1B/1D receptor antagonists and antidepressants in the forced swimming test. Eur J Pharmacol, 487, 133-42.

196. THAKKER, D. R., F. NATT, D. HUSKEN, P. H. VAN DER, R. MAIER, D. HOYER, AND J. F. CRYAN. 2005. siRNA-mediated knockdown of the serotonin transporter in the adult mouse brain. Mol.Psychiatry 10, 782-9. 
197. THOMPSON, A. J. \& LUMMIS, S. C. R. 2006. 5-HT3 receptors. Curr Pharm Des, $12,3615-30$.

198. TRIVEDI, M. H., FAVA, M., WISNIEWSKI, S. R., THASE, M. E., QUITKIN, F., WARDEN, D., RITZ, L., NIERENBERG, A. A., LeBOWITZ, B. D., BIGGS, M. M., LUTHER, J. F., SHORES-WILSON, K. \& RUSH, A. J. 2006. Medication augmentation after the failure of SSRIs for depression. N Engl J Med, 354, 1243-52.

199. VANDERMAELEN, C. P., \& AGHAJANIAN, G. K. 1983. Electrophysiological and pharmacological characterization of serotonergic dorsal raphe neurons recorded extracellularly and intracellularly in rat brain slices. Brain Res, 289, 109-19.

200. VARGA, V., SZEKELY, A. D., CSILlAG, A., SHARP, T. \& HAJOS, M. 2001. Evidence for a role of GABA interneurones in the cortical modulation of midbrain 5hydroxytryptamine neurones. Neuroscience, 106, 783-92.

201. VARNAS, K., HALLDIN, C., PIKE, V. W. \& HALL, H. 2003. Distribution of 5-HT4 receptors in the postmortem human brain--an autoradiographic study using [125I]SB 207710. Eur Neuropsychopharmacol, 13, 228-34.

202. VARNAS, K., THOMAS, D. R., TUPALA, E., TIIHONEN, J. \& HALL, H. 2004. Distribution of 5-HT7 receptors in the human brain: a preliminary autoradiographic study using [3H]SB-269970. Neurosci Lett, 367, 313-6.

203. VIDAL, R., PILAR-CUELLAR, F., DOS ANJOS, S., LINGE, R., TRECENO, B., VARGAS, V. I., RODRIGUEZ-GAZTELUMENDI, A., MOSTANY, R., CASTRO, E., DIAZ, A., VALDIZAN, E. M. \& PAZOS, A. 2011. New strategies in the development of antidepressants: towards the modulation of neuroplasticity pathways. Curr Pharm Des, $17,521-33$.

204. WARNER-SCHMIDT, J. L., FLAJOLET, M., MALLER, A., CHEN, E. Y., QI, H., SVENNINGSSON, P. \& GREENGARD, P. 2009. Role of p11 in cellular and behavioral effects of 5-HT4 receptor stimulation. J Neurosci, 29, 1937-46. 
205. WESOLOWSKA, A. 2007. Study into a possible mechanism responsible for the antidepressant-like activity of the selective 5-HT6 receptor antagonist SB-399885 in rats. Pharmacol Rep, 59, 664-71.

206. WESOLOWSKA, A. \& NIKIFORUK, A. 2007. Effects of the brain-penetrant and selective 5-HT6 receptor antagonist SB-399885 in animal models of anxiety and depression. Neuropharmacology, 52, 1274-83.

207. WESOLOWSKA, A. \& NIKIFORUK, A. 2008. The selective 5-HT(6) receptor antagonist SB-399885 enhances anti-immobility action of antidepressants in rats. Eur J Pharmacol, 582, 88-93.

208. WESOLOWSKA, A., NIKIFORUK, A., STACHOWICZ, K. \& TATARCZYNSKA, E. 2006. Effect of the selective 5-HT7 receptor antagonist SB 269970 in animal models of anxiety and depression. Neuropharmacology, 51, 578-86.

209. WESOLOWSKA, A., TATARCZYNSKA, E., NIKIFORUK, A. \& CHOJNACKAWOJCIK, E. 2007. Enhancement of the anti-immobility action of antidepressants by a selective $5-\mathrm{HT7}$ receptor antagonist in the forced swimming test in mice. Eur $\mathrm{J}$ Pharmacol, 555, 43-7.

210. Whale, R., Clifford, E. M., BhAgWAgAR, Z. \& COWEN, P. J. 2001. Decreased sensitivity of 5-HT(1D) receptors in melancholic depression. Br J Psychiatry, $178,454-7$.

211. Whale, R., Terao, T., COWEN, P., FREEMANTLE, N. \& GedDES, J. 2010. Pindolol augmentation of serotonin reuptake inhibitors for the treatment of depressive disorder: a systematic review. J Psychopharmacol, 24, 513-20.

212. WOOD, M. D. 2003. Therapeutic potential of 5-HT2C receptor antagonists in the treatment of anxiety disorders. Curr Drug Targets CNS Neurol Disord, 2, 383-7.

213. WOOLLEY, D. W. \& SHAW, E. 1954. A biochemical and pharmacological suggestion about certain mental disorders. Proc Natl Acad Sci U S A, 40, 228-231. 
214. ZARATE, C. A., JR., SINGH, J. B., CARLSON, P. J., BRUTSCHE, N. E., AMELI, R., LUCKENBAUGH, D. A., CHARNEY, D. S. \& MANJI, H. K. 2006. A randomized trial of an $\mathrm{N}$-methyl-D-aspartate antagonist in treatment-resistant major depression. Arch Gen Psychiatry, 63, 856-64. 
Box 1. Main characteristics of the serotonergic system in mammalian brain

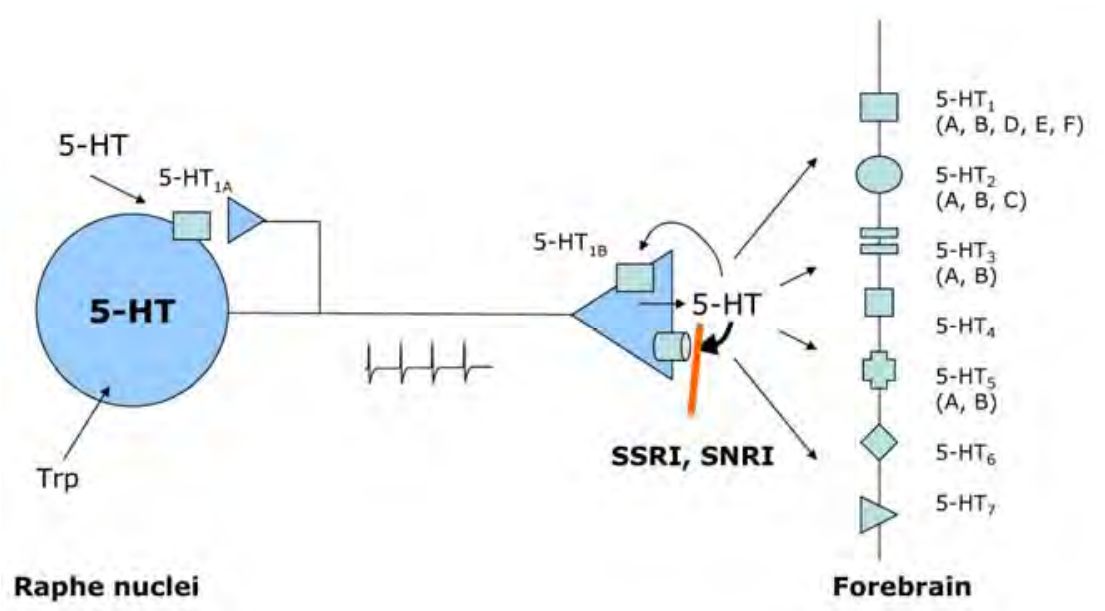

- Low number of neurons: 250.000 5-HT neurons in the human brain (out of a total of $\left.10^{11}\right)$

- Extensive arborisation $\left(>10^{6}\right.$ nerve terminals $\left./ \mathrm{mm}^{3}\right)$

- Innervation of the whole neuraxis

- Control of activity by descending (prefrontal cortex, lateral habenula, hypothalamus, etc.) and ascending (locus coeruleus, spinal cord) inputs to the raphe nuclei

- Slow and regular discharge (pacemaker neurons): strong homeostasis

- Neuronal activity dependent on sleep-wake cycles (REM-off neurons)

- Very sensitive to self-inhibition through activation of $5-\mathrm{HT}_{1 \mathrm{~A}}$ autoreceptors

- Rich neurochemistry: 14 different postsynaptic receptors

- Implication in a large number of physiological functions

- Mutual control with monoaminergic cell groups 


\section{Figure legends}

A
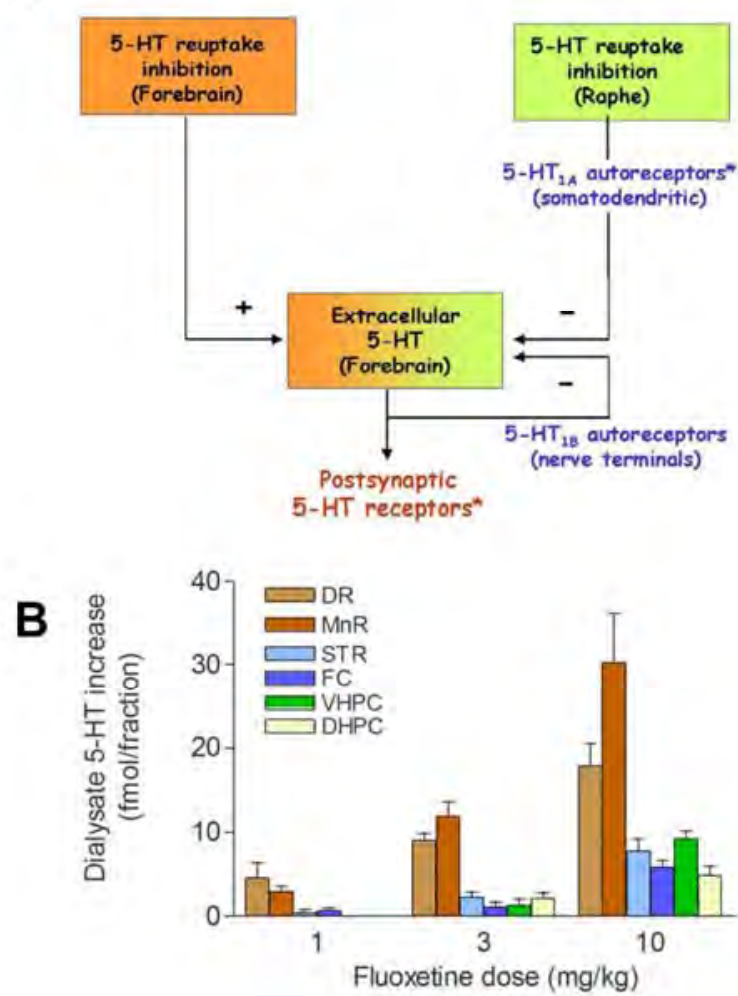

C

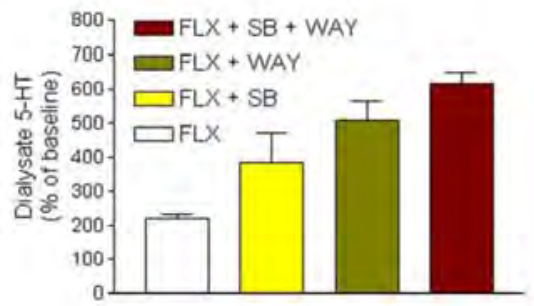

D

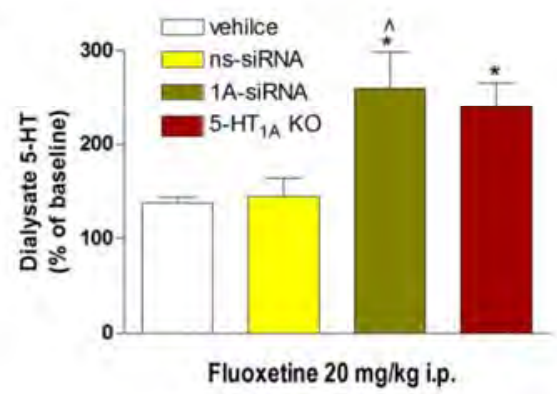

Fig. 1. Role of $5-\mathrm{HT}_{1 \mathrm{~A} / 1 \mathrm{~B}}$ autoreceptors in the mechanism of action of antidepressant drugs. A) Serotonin-enhancing drugs, such as the selective serotonin reuptake inhibitors (SSRIs) and the serotonin and norepinephrine reuptake inhibitors (SNRIs), exert two opposite actions on the active (extracellular) fraction of 5-HT in forebrain. On the one hand, SERT inhibition in forebrain nerve terminals increases the extracellular $5-\mathrm{HT}$ concentration in corticolimbic areas. On the other hand, the excess 5-HT evoked by inhibition of SERT (maximal density in the raphe nuclei due to the presence of a dense network of $5-\mathrm{HT}$ fibres (see $\mathrm{B}$ ) activates raphe $5-\mathrm{HT}_{1 \mathrm{~A}}$ autoreceptors, thus reducing serotonergic cell firing and impulse-dependent 5-HT release by forebrain axons. An additional negative feedback mechanism is exerted by the activation of 5$\mathrm{HT}_{1 \mathrm{~B}}$ autoreceptors in serotonergic nerve terminals. 5- $\mathrm{HT}$ autoreceptor desensitisation after 
repeated treatment reduces the efficacy of negative feedback mechanisms and allows the active 5-HT concentration to increase several-fold. B) Increase in extracellular concentration produced by the SSRI fluoxetine (FLX, 1, 3 and $10 \mathrm{mg} / \mathrm{kg}$ ) in six different regions of the rat brain. Note the large effect of SERT blockade by fluoxetine in the dorsal and median raphe nuclei at all doses in parallel with a moderate (if any) effect in forebrain regions. The effect of low doses is particularly relevant for clinical effects in depressed patients (20 $\mathrm{mg} /$ day for an average weight of $70 \mathrm{~kg}$, i.e. $0.3 \mathrm{mg} / \mathrm{kg}$.day in humans). C) The combined administration of the selective antagonists of 5- $\mathrm{HT}_{1 \mathrm{~A}}$ and $5-\mathrm{HT}_{1 \mathrm{~B}}$ receptors (WAY-100635, $0.3 \mathrm{mg} / \mathrm{kg}$ s.c. and SB224289, $4 \mathrm{mg} / \mathrm{kg}$ i.p., respectively) augmented the effect of the SSRI fluoxetine (10 mg/kg i.p.) on extracellular 5-HT concentration in rat prefrontal cortex, mimicking the effects of autoreceptor desensitisation. D) Similarly, the knockdown of 5- $\mathrm{HTH}_{1 \mathrm{~A}}$ autoreceptors induced by a conjugated siRNA directed towards $5-\mathrm{HT}_{1 \mathrm{~A}}$ autoreceptors (C-1A-siRNA) augmented the effect of fluoxetine (20 mg/kg i.p.) on extracellular $5-\mathrm{HT}$ in mouse prefrontal cortex up to the level seen in constitutive $5-\mathrm{HT}_{1 \mathrm{~A}}$ knockout mice $(1 \mathrm{~A}-\mathrm{KO})$. Note the small effect of fluoxetine in two groups of control mice (pre-treated with vehicle and nonsense siRNA -C-ms-siRNA, respectively). Results are means \pm SEM values of extracellular $5-\mathrm{HT}$ in the various experimental groups. Redrawn from data in Hervás and Artigas (1998), Hervás et al. (2000), and Bortolozzi et al. (2012). Abbreviations: DR, dorsal raphe nucleus; DHPC, dorsal hippocampus; MnR, median raphe nucleus; PFC, prefrontal cortex; STR, dorsal striatum; VHPC, ventral hippocampus. Panel A redrawn from Artigas et al. (2001) with permission. 

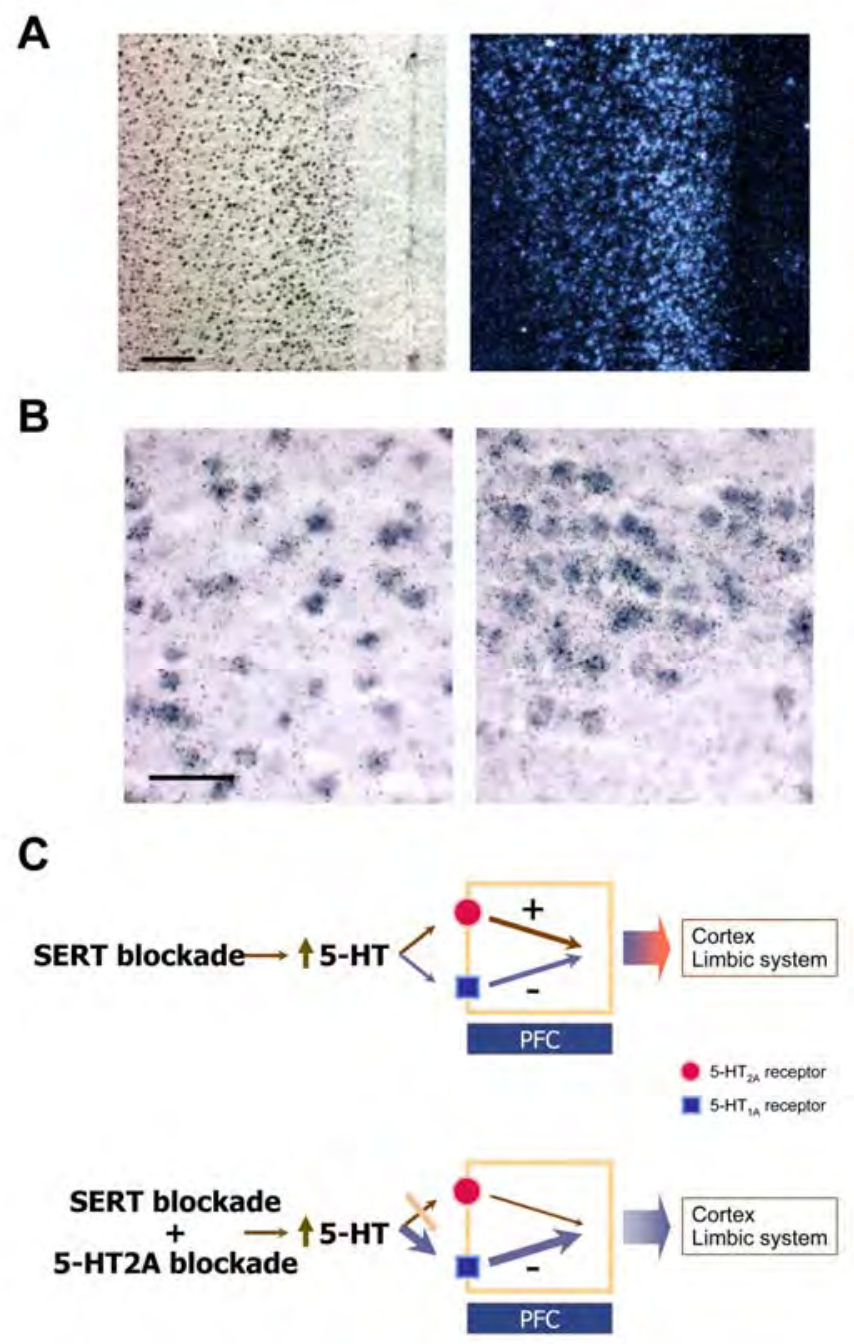

Fig. 2. Schematic representation of the putative antidepressant mechanism of $5-\mathrm{HT}_{2 \mathrm{~A}}$ receptor blockade. A) Low magnification image from the prelimbic area of the medial prefrontal cortex (mPFC) showing the presence of cells expressing 5- $\mathrm{HT}_{1 \mathrm{~A}}$ (left panel) and 5- $\mathrm{HT}_{2 \mathrm{~A}}$ receptor mRNA (right panel) labeled by double in situ hybridization using nonradioactive (digoxygenin, left) and radioactive $\left({ }^{33} \mathrm{P}\right.$, right) oligonucleotides. Note the abundance of cells expressing one or other receptor, particularly in layers II-V. B) High-resolution image from the same area showing individual cells expressing both receptor transcripts, as denoted by the simultaneous presence of background dark cellular profiles (5- $\mathrm{HT}_{1 \mathrm{~A}}$, digoxygenin-labeled) and black silver grains (5- 
$\mathrm{HT}_{2 \mathrm{~A}},{ }^{33} \mathrm{P}$-labeled). C) Upper panel. The excess 5 - $\mathrm{HT}$ produced by SERT inhibition in prefrontal cortex (PFC) activates excitatory 5- $\mathrm{HT}_{2 \mathrm{~A}}$ and inhibitory 5- $\mathrm{HT}_{1 \mathrm{~A}}$ receptors in pyramidal neurons projecting to other cortical as well as subcortical areas, including the limbic system. Lower panel. Due to the large coexpression of $5-\mathrm{HT}_{2 \mathrm{~A}}$ and $5-\mathrm{HT}_{1 \mathrm{~A}}$ receptors in $\mathrm{PFC}$ neurons (ca. 80\%; Amargós-Bosch et al., 2004; see B), the blockade of 5- $\mathrm{HT}_{2 \mathrm{~A}}$ receptors enhances $5-\mathrm{HT}_{1 \mathrm{~A}}$ receptor-mediated neurotransmission, thus changing the top-down control of PFC on corticolimbic networks. Panels A and B taken from Amargós-Bosch et al. (2004) with permission. 


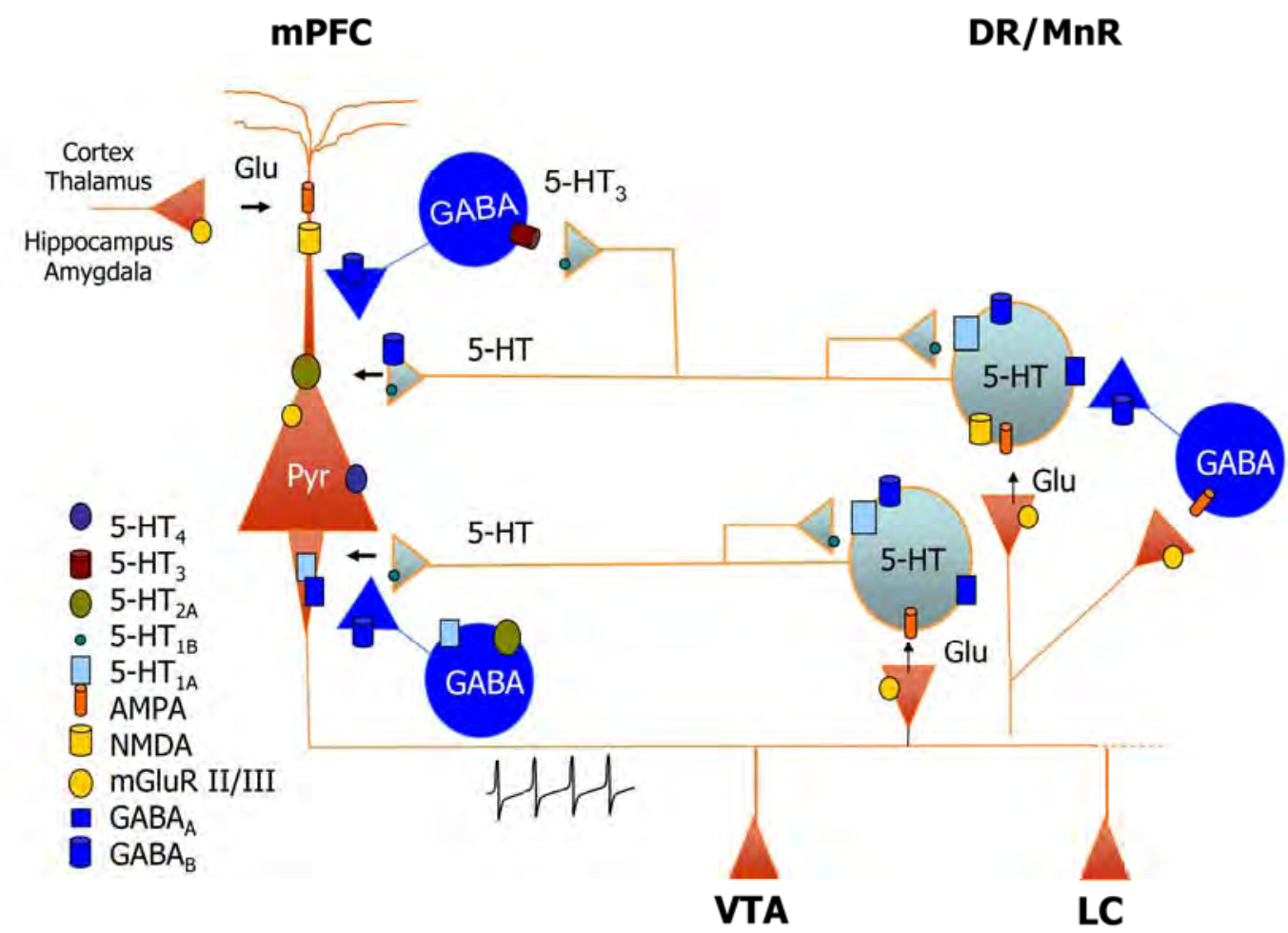

Fig. 3. Schematic representation of the functional connectivity between the medial prefrontal cortex (mPFC) and the dorsal and median raphe nuclei (DR(MnR), in relationship to the putative antidepressant mechanism of $5-\mathrm{HT}_{3}$ receptor blockade. The activity of pyramidal neurons in PFC is controlled by a balance between excitatory inputs (AMPA, NMDA) from other cortical areas, the thalamus, the hippocampus and the amygdala, and inhibitory inputs (mainly $G A B A_{A}$, $\mathrm{GABA}_{\mathrm{B}}$ and mGluRII/III). Monoamines may play both excitatory and inhibitory roles, depending on the receptor activated. $5-\mathrm{HT}_{3}$ receptors are.expressed by GABAergic interneurons in the hippocampal formation (Morales and Bloom, 1997) and the medial prefrontal cortex (mPFC; Puig et al., 2004). 5- $\mathrm{HT}_{3}$ receptor-containing interneurons are located in upper cortical layers than those expressing $5-\mathrm{HT}_{2 \mathrm{~A}}$ receptors, indicating that $5-\mathrm{HT}_{3}$ receptors control excitatory inputs onto apical dendrites. $5-\mathrm{HT}_{3}$ receptors are excited by the physiological release of $5-\mathrm{HT}$, this 
enhancing the local inhibitory tone via $\mathrm{GABA}_{A}$ and $\mathrm{GABA} \mathrm{A}_{\mathrm{B}}$ receptor activation. $5-\mathrm{HT}_{3}$ receptor blockade may thus decrease local negative feedback on 5-HT release mediated by terminal $\mathrm{GABA}_{B}$ heteroreceptors. Additionally, $5-\mathrm{HT}_{3}$ receptor blockade may decrease the $\mathrm{GABA}_{A}$ receptor-mediated tone on mPFC neurons projecting to midbrain, thus enhancing the activity of the ascending brainstem monoaminergic systems (serotonergic neurons of the DR/MnR; dopaminergic neurons of the ventral tegmental area, VTA; noradrenergic neurons of the locus coeruleus, LC) that are under the excitatory control of the PFC (Gabbott et al., 2005). Both mechanisms may account for the augmentation of SSRI effects by the selective $5-\mathrm{HT}_{3}$ receptor antagonist ondansetron (Mork et al., 2012). Abbreviations: DR, dorsal raphe nucleus; LC, locus coeruleus; MnR, median raphe nucleus; VTA, ventral tegmental area. 